Türk Coğrafya Dergisi
Sayı 63: 23-42, istanbul
http://www.tcd.org.tr

Hakemli Makale
Reviwed Article

\title{
Kahta Çayı Aşağı Havzası'nın (Adıyaman) jeomorfolojik özellikleri
}

\author{
The geomorphologic characteristics of lower Kahta Stream basin (Adıyaman)
}

Murat SUNKAR $^{a}$ Zeynel KARATAŞ

\section{öz}

Bu çalışmada, Güneydoğu Toroslar ve Adıyaman Havzası üzerinde yer alan Kahta Çayı Aşağı Havzası'nın jeomorfolojisi incelenmiştir. Jeomorfoloji çalışmalarında bazı özel sahalar geniş alanlardaki jeomorfolojik sorunların çözümünde kilit vazifesi görmektedir. Kahta Çayı Aşağı Havzası da Adıyaman Havzası ve çevresinin jeomorfolojik özelliklerinin belirlenmesi açısından kilit konumundadır. Kahta Çayı, kaynağını Güneydoğu Toroslar'dan almakta olup Fırat Nehri'nin en önemli kollarından biridir. Adıyaman Havzası kuzeyinde yer alan Kahta Çayı Havzası, Doğu Anadolu Fayı, Güneydoğu Anadolu Bindirmesi ve Adıyaman Fayı tarafından kesilerek deforme edilmiştir. Bu tektonik yapı özelliği nedeniyle, morfolojik gelişimde genç tektonik hareketlerin etkisi belirgindir. Kahta Çayı Aşağı Havzası'nda antiklinallere karşılık gelen dağlık alanlar faylarla kesilerek yükselmiş, havza tabanları ise alçalmıştır. Bu tektonik gelişime ayak uyduran Kahta Çayı ise yatağı içerisinde gömülerek derin boğazlar oluşturmuştur. Kahta Çayı Aşağı Havzası'nın kuzeyindeki dağlık alanlar ve bunların üzerindeki yüksek platolar, Adıyaman Havzası'nı oluşturan alçak platolar ile Kahta Çayı Vadisi ana jeomorfolojik birimleri oluşturmaktadır.

a) Fırat Üniversitesi, İnsani ve Sosyal Bilimler Fakültesi, Coğrafya Bölümü.

b) Adıyaman Fen Lisesi. Kuzeydeki dağılık alanlar üzerinde kıvrımlı ve kırıklı yapıda gelişen şekilleri görmek mümkündür. Akarsuların antiklinalleri kestiği alanlarda klüzler, faylı yamaçlarda kütle hareketleri, karstik şekiller ve taraçalar diğer önemli jeomorfolojik birimlerdir. Anahtar Kelimeler: Jeomorfoloji, Güneydoğu Toroslar, Adıyaman Havzası, Kahta Çayı, Kahta Çayı Aşağı Havzası.

Geliş/Received: 21.10.2014 Kabul /Accepted: 11.12.2014

Sorumlu yazar/Corresponding author (M. SUNKAR) msunkar@firat.edu.tr

\section{ABSTRACT}

This study aimed at investigation the geomorphologic characteristics of lower Kahta Stream Basin located over the belt of South-eastern Taurus Mountains and Adiyaman basin. In geomorphologic investigations, some specific areas play a key role in overcoming a variety of geomorphic problems. Lower Kahta Stream Basin, as well, plays a crucial role in specifying the geomorphologic characteristics of Adlyaman basin and its surrounding. The source of Kahta Stream comes from the Southeastern Taurus and also it is one of the most important tributaries of the Euphrates River. Kahta Stream Basin located in the north of Adiyaman basin had been deformed as being intersected by Eastern Anatolia fault, Southeastern Anatolia Thrust and Adiyaman fault. Because of its tectonic structure, the effect of recent tectonic moves is apparently seen in its morphological development. In the lower Kahta Stream Basin, the mountains areas in the same with anticlines have been intersected by the faults and so it has risen, while the bases of the basin have descended. Catching up with this tectonic change, the Kahta Stream has formed deep narrow straits by sinking into its streambed. The mountainous areas in the north of lower Kahta Stream Basin and high plateaus on them form the low plateaus and the main geomorphologic units of the Kahta Stream Valley. It is possible to see the forms evolving in the folded and faulted structure on the mountainous areas in the North. In the areas where streams intersect with the anticlines, mountain passes, mass movement on faulted slopes, karstic forms and terraces are the other important geomorphologic units in the lower basin.

Keywords: Geomorphology, Southeastern Taurus Mountains, Adıyaman Basin, Kahta Stream, Lower Kahta Stream Basin.
Kaynağını Güneydoğu Toroslar'dan alan Kahta Çayı, Fırat Nehri'nin en önemli kollarından birini oluşturmaktadır. Üç önemli kolun birleşmesiyle oluşan Kahta Çayı, ortalama 45$50 \mathrm{~km}$ uzunluğunda olup, geniş bir alanın sularını topla- 
maktadır (Şekil 1). Kahta Çayı Havzası'nın kuzey bölümü Güneydoğu Toroslar, güney bölümü Adıyaman Havzası'nda kalmaktadır.

Inceleme alanı sınırları içerisinde litolojik yapı, Mesozoyik'ten günümüze kadar olan zaman aralığında oluşmuş mağmatik ve sedimanter kayaçlardan oluşmaktadır. Kuzeydeki bindirme kuşağı ile sınırlandırılan Mesozoyik birimleri, inceleme alanındaki en yaşlı birimi oluşturmaktadır. Faylarla kesilmiş olan antiklinaller ise Eosen birimlerinden oluşmaktadır. Kahta'nın da içerisinde yer aldığı Adıyaman Havzası ve Kahta kuzeyindeki antiklinaller arasındaki, senklinal havzalarını dolduran birimler, Üst Miyosen ve PliyoKuvaterner döneminde oluşmuştur (Sungurlu vd., 1991). Yarlıca Dağı kuzeyindeki havzadan başlayıp, eski Fırat Vadisi'ne kadar Kahta Çayı Vadisi boyunca geniş alanlarda görülen Kuvaterner birimleri, taraça dolgularını oluşturmaktadir.

Kahta Çayı Aşağı Havzası'na karşılık gelen inceleme alanında, 700-900 m yükseltileri arasındaki düzlükler alçak platoları, 1000-1300 m yükseltileri arasındaki düzlükler yüksek platoları oluşturmaktadır. Kuzeydeki yüksek platoların büyük bölümü dağlık alanlar üzerinde yer almaktadır. Kuzeydeki dağlık alanlar, bu dağlık alanların arasındaki küçük havzalar, Adıyaman Havzası ve Kahta Çayı Vadisi ana jeomorfolojik birimleri oluşturmaktadır. Bu ana birimler dışında, inceleme alanında yapısal şekiller de gelişmiştir.

Kahta Çayı Havzası, kıvrılma ve kırılma hareketleri sonucunda oldukça deforme olmuş engebeli bir topografyaya sahiptir. Havzanın kuzey bölümü Doğu Anadolu Fayı, güney bölümü ise Güneydoğu Anadolu Bindirmesi ve Adıyaman Fayı etkisinde fazla parçalanmıştır (Karataş, 2012). Aşağı havzada en önemli dağlık alanları Yarlıca (Hüseyin Tepe, 1436 m), Kızıldağ ve Nemrut Dağı oluşturmaktadır. Yarlıca Dağı kabaca D-B doğrultusunda, Kızıldağ ve Nemrut Dağ
KD-GB doğrultusunda uzanmaktadır. Yarlıca Dağı'nın tamamına yakını, Kızıldağ ve Nemrut dağlarının bir bölümü inceleme alanı içerisinde kalmaktadır.

Havzanın faylanma sonucunda oldukça deforme olması, engebeli bir topografyanın oluşumunu sağlamıştır. Ayrıca, havza genelinde litolojik yapı aşınıma karşı dayanıksız olup, doğal bitki örtüsü tahrip edilmiştir. Bu yapısal özellikler ve yörede etkili olan iklim nedeniyle, havza genelinde çok şiddetli erozyon yaşanmaktadır. Atalay ve Mortan'a göre (2006) Kahta Çayı yılda 1 km²'den 4000 ton malzeme taşımaktadır. Yukarı havzadan taşınan malzeme, aşağı havzada dağlık alanlar arasındaki düzlük alanlarda biriktirilmektedir. Yarlıca Dağı kuzeyinde Alikan, güneyinde Gebeli ve daha güneyde Adıyaman havzalarında biriktirilen bu malzeme, kalın taraça dolgularını oluşturmaktadır. Kahta Çayı, bu havzalarda geniş yatağı içerisinde örgülü drenaj ağına sahiptir. Havzanın \% 0.8'i (12.4 km²) akarsu taşkın yatağından oluşmaktadır (Elmastaş, 2008). Taşkın yatağının geniş alan kaplaması, morfolojik özellikler ve drenaj ağı ile ilişkilidir. Ayrıca taşkın yatağının geniş olması, debinin çok yüksek ve düzensiz olduğunu da göstermektedir (Sunkar ve Karataş, 2012a; 2012b).

Yörenin şekillenmesinde paleotektonik hareketlerden ziyade genç tektonik hareketlerin etkisi belirgindir. Neotektonik dönemde dağlık alanlar faylarla kesilerek yükselmiş, havza tabanları ise alçalmıştır. Bu duruma ayak uyduran Kahta Çayı ise yatağı içerisinde gömülerek derin boğaz ve vadileri oluşturmuştur. Kahta Çayı'nın da içerisinde yer aldığı Fırat Sistemi; Pleyistosen boyunca iklim koşulları ve taban seviyesi değişmelerinin etkisiyle menderesli bir şekilde gömülmüş, özellikle sert kayaçların olduğu alandaki bu gömülmelerle epijenik boğazlar oluşmuştur (Erol vd., 1987).

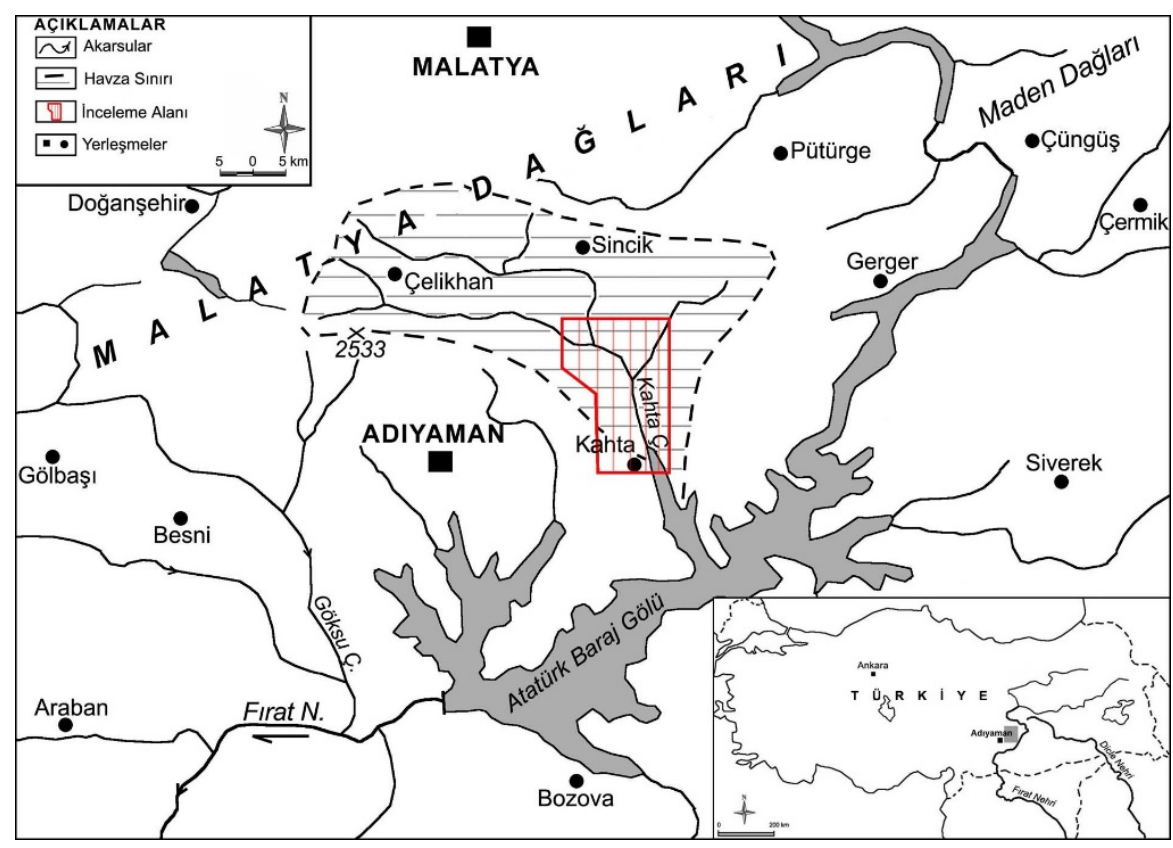

Şekil 1. Kahta Çayı Aşağı Havzası'nın (Adıyaman) lokasyon haritası.

Figure1. The location map of Kahta Stream (Adıyaman) lower basin. 
Kahta Çayı, Fırat Nehri'nin önemli bir kolu olduğu için bu nehrin gelişim sistemi ile paralellik göstermektedir. Fırat Nehri, Pleyistosen süresince değişen iklim koşulları ve kaide seviyeleri etkisiyle, menderesleri ile birlikte, olduğu gibi gömülmüş, özellikle dayanıklı kayaçlar içinde epijenik boğazlarını kazmıştır. Fırat Nehri'nin Pleyistosen içindeki bu gömülmesi, Pleyistosen iklim salınımlarının etkisi altında dura dura olmuş, her duraklama döneminde bir vadi tabanı oluşup, yarılmanın hızlandığı dönemlerde bu tabanlar yarılarak dört ana seki basamağı (S1-S4) oluşmuştur. Bu taraçalardan Alt Pleyistosen'e ait olanlar, bugünkü vadi tabanlarından 80-100 ve 50-70 m yüksekte, Orta ve Üst Pleyistosen'e dahil olanlar $25-30$ ve $10-15$ m yüksekte yer almaktadır (Erol vd., 1987). Fırat Nehri için belirlenen bu seki basamakları sistemdeki bütün akarsular için geçerli olup tektoniğin etkisiyle yerel farklılıklar gösterebilmektedir. Türkiye sınırları dışında da Fırat Nehri taraçaları, tektoniğin etkisiyle farklı yükseltilerde yer almaktadır (Demir vd., 2004). Karadoğan (2005) tarafından yapılan çalışmada ise Kahta Çayı'na bağlı oluşan taraçalar, Göksu Çayı taraçaları referans alınarak (T1 100-110 m; T2 70-80 m; T3 30-40 m ve T4 10-15 m) başlıca dört grupta toplanmıştır. Bu çalışma kapsamında, tarafımızdan Kahta ve Göksu çayı vadilerinde yapılan çalışmalara göre, her iki vadide taraçaların tektoniğin etkisiyle 150-160 m'ye kadar çıktığı görülmüştür. Vadi tabanına göre en yüksek taraçanın bu kadar yüksekte yer almasında, genç tektonik hareketler etkili olmuştur. Kahta Çayı taraçaları vadi tabanına göre olan yükseltileri dikkate alınarak 6 grupta incelenmiştir (T1 90-100 m; T2 50-70 m; T3 30-40 m; T4 10-20 m; T5 3-5 m; T6 1-2 m). Bunlardan 1$2 \mathrm{~m}$ taraçaları 3-5 m taraçalarına dahil edilerek 5 taraça sistemi tanımlanmıştır (Karataş, 2012; Sunkar ve Karataş, 2012a; 2012b).

Bu çalışmada, Kahta Çayı Aşağı Havzası'nın jeomorfolojik özelliklerinin araştırılması amaçlanmıştır. Kahta Çayı Aşağı Havzası, jeomorfolojik şekiller açısından oldukça zengin ve çeşitlilik göstermektedir. Ayrıca içerisinde yer aldığı sahanın jeomorfolojik gelişiminin açıklanması bakımından kilit konumuna sahiptir. Bu özellikler dikkate alınarak havzadaki yer şekillerinin oluşum ve gelişimlerinin açıklanması amacıyla böyle bir çalışma hazırlanmıştır. Çalışma alanının sınırlarının belirlenmesinde ise hidrografik sınır dışında morfolojik durum dikkate alınmıştır.

\section{MATERYAL ve YÖNTEM}

Kahta Çayı Aşağı Havzası'nın jeomorfolojik özelliklerinin incelendiği bu çalışmada, analitik jeomorfoloji araştırma yöntemi kullanılmıştır. Bu çalışma, 1-Hazırlık çalışmaları, 2Jeolojik ve Jeomorfolojik taslak haritalarının hazırlanması, 3-Arazi çalışmalarıla taslak haritaların düzenlenmesi, 4Arazi verilerine göre Jeomorfoloji haritasının hazırlanması ve metin yazımından oluşan 4 aşamada tamamlanmıştır.

Hazırlık çalışmaları kapsamında; Kahta ve çevresinde yapılmış olan Jeoloji ve Jeomorfoloji çalışmaları ile Kahta Çayı Havzası'nı içine alan 1/25.000 ölçekli topografya haritaları temin edilmiştir. Çalışma alanını kapsayan DEM (Digital
Elevation Model) ve uydu görüntüleri, internetten ücretsiz indirilerek harita analizleri (profil, eğim ve yamaç) yapılmıştır. İkinci aşamada, morfolojik özelliklerin belirlenmesi amacıyla, 1/25.000 ölçekli topografya haritaları üzerinden taslak jeomorfoloji haritası çizilmiştir. Bu hazırlıktan sonra, TPAO Adıyaman Bölge Müdürlüğü tarafından hazırlanan ve çalışma alanını kapsayan jeoloji haritaları üzerinde, jeolojik birlikler birleştirilerek taslak jeoloji haritası oluşturulmuştur. Arazi öncesinde yapılan bu hazırlık çalışmalarından sonra farklı yıl ve uygun tarihlerde arazi çalışmaları yapılmıştır.

Üçüncü aşamayı oluşturan arazi çalışmaları kapsamında, Kahta Çayı Havzası'nın tamamında arazi gözlemleri yapılmıştır. Daha sonra aşağı havzada detaylı gözlem ve ölçümler yapılarak, arazide görülen morfolojik birimler önceden hazırlanan taslak haritalara aktarılmıştır. Arazi çalışmalarında akarsu taraçalarının tesbiti amacıyla, taraça dolgularından çeşitli analizler (Çakıl analizleri, XRD, SEM, EDX, ICPMS) için numuneler alınmıştır. Ayrıca, arazi çalışmalarında çok sayıda dijital fotoğraf çekilerek, uygun olanları kullanılmıştır.

Dördüncü ve son aşamada arazi çalışmaları neticesinde elde edilen verilere göre, bu çalışmada kullanılan haritalar hazırlanmıştır. Haritaların hazırlanmasında, Coğrafi Bilgi Sistemleri (CBS) kullanılmıştır. Bu sistemde, 1/25.000 ölçekli topografya haritaları sayısallaştırılarak raster veri formatına dönüştürülmüştür. Arazi çalışmaları kapsamında düzeltilen haritalar da sayısallaştırılarak raster veri olarak sisteme eklenmiştir. Bu veriler çakıştırılarak, sayısal ortamda jeoloji ve jeomorfoloji haritaları hazırlanmıştır. Jeomorfoloji haritasının çiziminde öncelikle sürekli ve mevsimlik akarsular, daha sonra sırasıyla yüzeyler, yamaçlar, fay diklikleri, boğazlar ve diğer jeomorfolojik şekiller ayrı katmanlar olarak çizilmiştir. Yüzeyler, taraçalar ve heyelan alanları poligon olarak çizilmiş ve uygun şekilde renklendirilmiştir. Bu şekilde hazırlanan haritalar, çıktı formatında düzenlenmiş ve TiF olarak kaydedilmiştir. Hazırlık ve arazi çalışmalarına göre toplanan veriler ile oluşturulan haritalara göre çalışma metni hazırlanmıştır.

\section{ÇALIŞMA ALANININ JEOLOJiK ÖZELLIKLERI}

Kahta Çayı Havzası'nın kuzeyinde Paleozoyik-Mesozoyik metamorfitler (mermer, şist), güneyinde ise Mesozoyik volkanik, sedimanter ve ofiyolitler ile Eosen dönemine ait kireçtaşları geniş alan kaplamaktadır. Kahta Çayı Aşağı Havzası'nda ise Tersiyer birimleri geniş yüzeyleme alanına sahiptir (Şekil 2). Bölgenin petrol potansiyeli nedeniyle ayrıntılı jeolojik ve sedimantolojik incelemesi yapılmıştır. Özellikle Adıyaman TPAO Bölge Müdürlüğü tarafından çeşitli ölçeklerde jeoloji haritaları hazırlanmıştır.

Malatya ve Adıyaman Havzası arasında, Güneydoğu Toroslar üzerinde yer alan Kahta Çayı Havzası, jeolojik ve tektonik açıdan kendi içerisinde çok farklı özellikler göstermektedir. İnceleme alanı dışında, kuzeyde Paleozoyik metamorfitler geniş yüzeyleme alanına sahip olup, Doğu Anadolu Fay Zonu (DAFZ) tarafından kesilerek büyük dilim- 
lere ayrılmıştır. İnceleme alanı ise bindirme ve faylarla deforme edilmiş, karmaşık bir yapı özelliği göstermektedir.

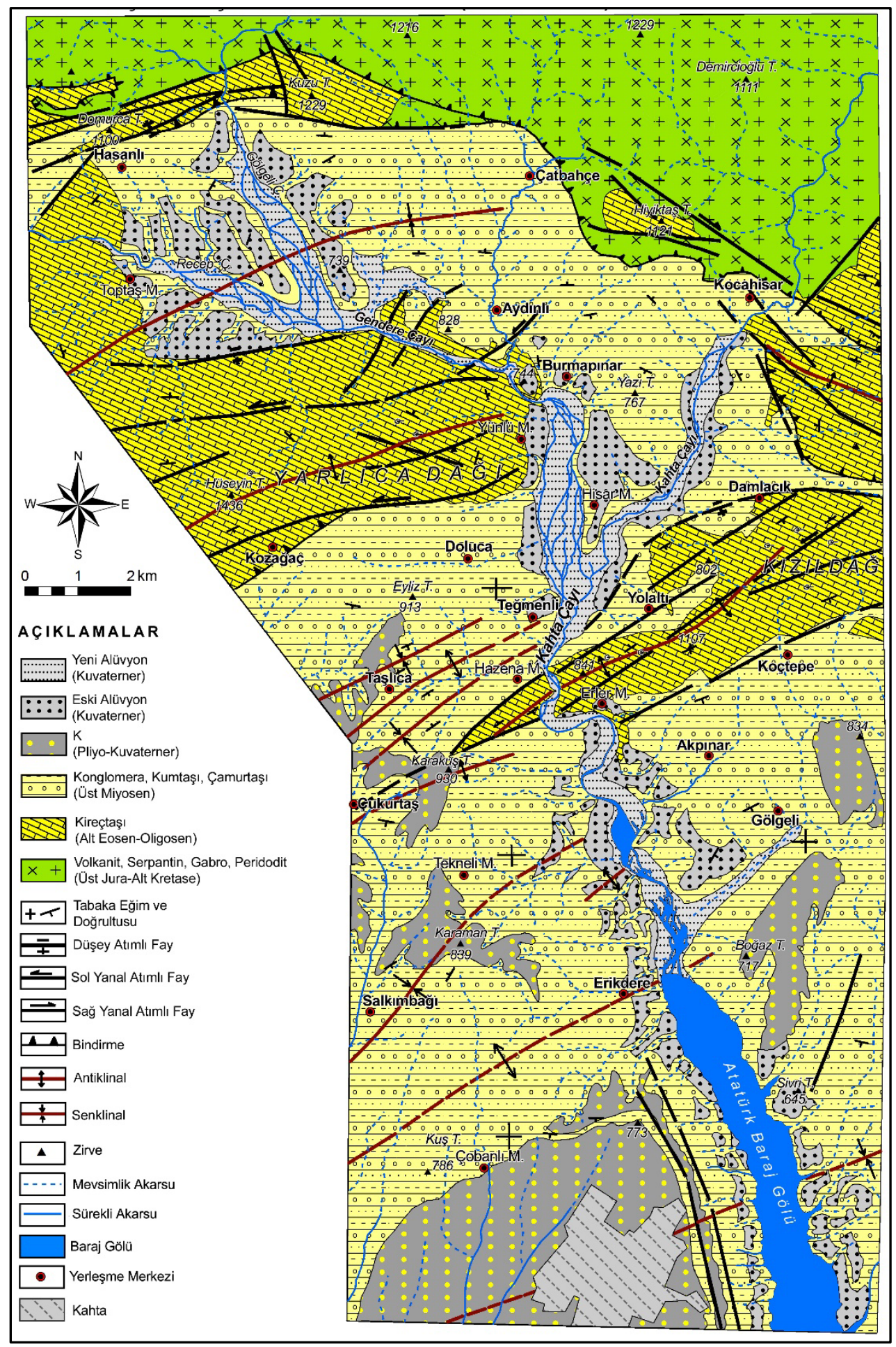

Şekil 2. Kahta Çayı Aşağı Havzası'nın (Adıyaman) jeoloji haritası (Sungurlu vd., 1991'den değiştirilerek hazırlanmıştır).

Figure 2. The geological map of the Lower Kahta Stream Basin (It was prepared after modification, Sungurlu et al., 1991).

\section{Sahanın Litolojik Özellikleri}

\section{Mesozoyik}

Kahta Çayı Aşağı Havzası'nın kuzeyinde geniş yüzeyleme alanına sahip volkanik, sedimanter ve ofiyolit grubundan oluşan birim Koçali Karmaşığı'nı oluşturmaktadır (Şekil 2). Bu birim ilk kez Sungurlu (1974) tarafından Adıyaman kuzeyinde Koçali dolaylarında tanımlanmış ve bu çalışmadan sonra bu ad benimsenmiştir. İnceleme alanında Koçali Karmaşı̆̆ı'nın güneyinde, Alt Eosen-Oligosen ve Üst Miyosen birimleri yüzeylemektedir. Bu alanda, Koçali Karmaşığı bindirme ile Şelmo Formasyonu'nun üzerine gelmektedir (Öğrenmiş, 2006). Koçali doğusundaki tip kesitinden Dogger yaşını veren fosil bulguları elde edilmiştir. Birim Triyas'da Anadolu ve Arap levhaları arasında oluşmaya başlayan Neotetis okyanusunun ortasındaki sırtta oluşan ofiyolitik kaya toplulukları ile bu 
ofiyolitik karmaşık üzerinde çökelen, derin deniz sedimanları ve okyanus ortası tümseklerde oluşan sığ karbonat yığışımlarının, tektonik sürüklenimlerle bir karmaşık oluşturması ile bugünkü karakterini kazanmıştır (Günay, 1998).

\section{Tersiyer}

\section{Alt Eosen Oligosen}

İnceleme alanında, Alt Eosen-Oligosen döneminde oluşan kireçtaşları kuzeyde Koçali Karmaşığı güneyinde parçalar halinde, Yarlıca, Kızıldağ ve Nemrut dağlarında ise geniş alanlı yüzeylemelere sahiptir (Şekil 2). Bu döneme ait birimlerin önemlilerini Hoya ve Fırat formasyonu oluşturmaktadır. Bu birimler, Güneydoğu Anadolu'da Hoya Formasyonu'nun yüzeylediği alanlarda, genelde dik yarlar oluşturan kireçtaşları ile bunların diyajenetik değişimleri ile oluşan dolomitlerden oluşmaktadır (Yılmaz ve Duran, 1997). Yarlıca Dağı doğusu ve daha doğuda görülen Fırat Kireçtaşları, yaş ve litolojik özellikleri nedeniyle Hoya Formasyonu içerisinde değerlendirilmiştir.

Eosen döneminde tüm Güneydoğu Anadolu Bölgesi'nde sığ karbonatların çökelimine uygun koşullar egemen olmuş ve Midyat Karbonatları çökelmiştir. İri bentik fosilli biyoklastik sığ ortam ürünü Hoya Formasyonu ile başlayan istif, denizin giderek derinleşmesi ile pelajik fosilli, killi tebeşirli kireçtaşı-marn litolojisindeki Gaziantep Formasyonu ile devam etmiştir. Oligosen sonunda, ortamın sığlaşmasıyla, platform alanında sedimantasyon sığ ortam ürünü kireçtaşları ile devam ederken, kuzey alanlarda kısa bir aşınma fazını takiben Alt Miyosen'de resifal kireçtaşı litolojisinde Fırat Formasyonu çökelmiştir (Sungurlu, 1974; Günay, 1998; Özdemir ve Ünlügenç, 2013).

Hoya Formasyonu'nda yapılan mikro paleontolojik incelemeler birimin Alt Eosen-Alt Oligosen yaş konakları arasında çökeldiğini göstermiştir (Yılmaz ve Duran, 1997).

\section{Üst Miosen}

İnceleme alanında Üst Miyosen döneminde oluşan konglomera, kumtaşı, çamurtaşı ve kiltaşı ardalanmasından oluşan birim, en geniş yüzeyleme alanına sahiptir (Şekil 2). Güneydoğu Anadolu Bölgesi'nde yaygın olarak görülen bu birim, Şelmo Formasyonu olarak tanınmaktadır. Bölgede Anadolu ve Arap levhalarının çarpışmasını takip eden dönemde kuzeydeki dağlık alanlarda hızlı yükselme ve aşınım devresi başlamıştır. Bu yükselme ve aşınım daha güneyde yeni bir sedimantasyon sürecini başlatmıştır. Bu dönemde oluşan genç dolgular da daha yaşlı birimleri örtmüştür. Güneydoğu Toroslar'ın güneyindeki ön çukurluğun tamamen kapanması ile Şelmo Formasyonu başlangıçta gölsel, daha sonra karasal ortam çökellerini oluşturmuştur (Fotoğraf, 1).

Karasal dolgulardan oluşan formasyonun kalınlığı, kuzeyde 40-150 m, Adıyaman Havzası'nın merkezi ve doğu kesimlerinde ise $750 \mathrm{~m}^{\prime}$ ye ulaşmaktadır. Bu birimin alt kesimleri açık gri renkli beyaz karbonatlı polijenik elemanlı şeyl ve kum taşlarından; üst kesimleri ise kırmızımsı kirli sarı renkli kiltaşı, kumtaşı ve konglomera ardalanmasından oluşmaktadır (Yılmaz ve Duran, 1997).
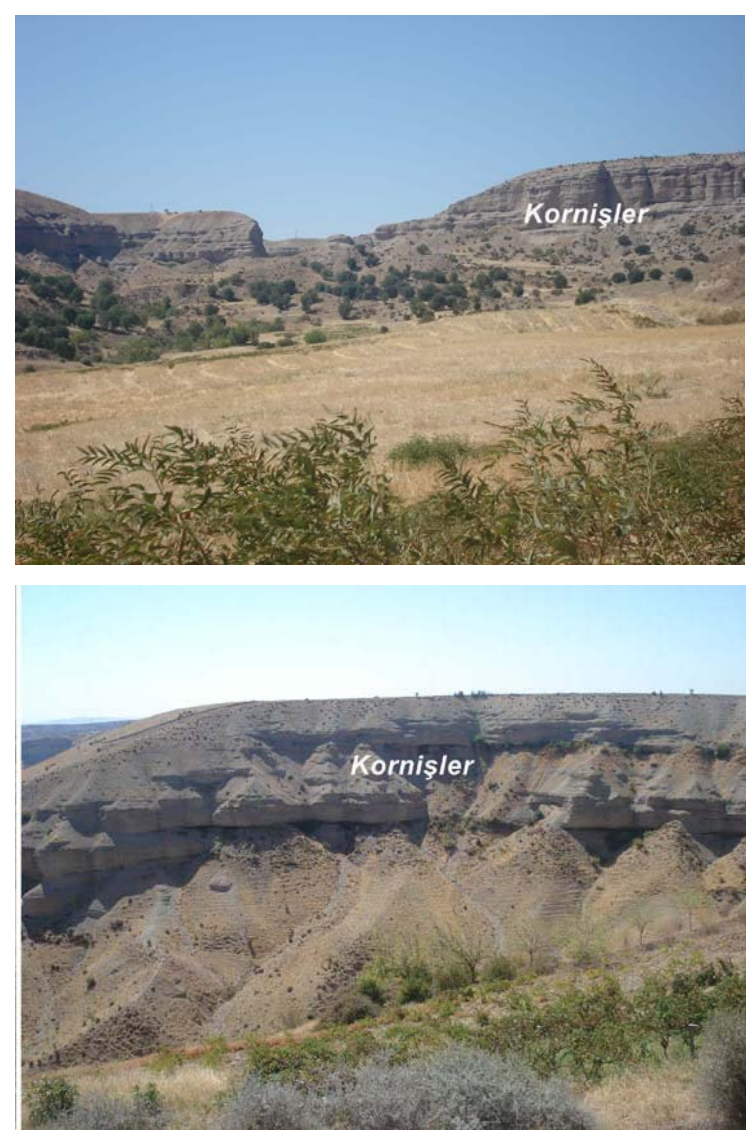

Fotoğraf 1. Kahta kuzeyinde, Erikdere köyü çevresinde konglomera ve çamurtaşı ardalanmasından oluşan Şelmo Formasyonu yüksek kornişler oluşturmaktadır.

Photo 1. The Şelmo formation which is made up of the alternation of conglomerate and mudstone forms high ledges.

Erikdere batısında ve kuzeyinde, kalınlığı 30 m'yi bulan konglomera tabakalarının altında yer alan çamurtaşı tabakalarının üstünde, omurgalı fosilleri görülmüştür. Güneydoğu Anadolu Bölgesi'ne ait ilk memeli fosil bulguları olan bu fosillerin varlığına ilk kez Meriç (1965) tarafından değinilmiş olup, yazarlar tarafından gerçekleştirilen çalışma sırasında da bunlara rastlanılmıştır. Memeli fosil kalıntıları, Kahta ilçesi Erikdere köyü çevresinde Şelmo Formasyonu'nun en alt birimi içerisinde bulunmaktadır. Bu memeli fosillere yönelik yapılan incelemelerde; Amphiorycteropus gaudryi, Hipparions sp. I (orta boyutlu) ve II (küçük boyutlu), Ancylotherium pentelicum, Gazelle sp., Pacthytragus sp., Prostrepsiceros sp., ve Giraffidea indet türlerinden oluşan fauna bileşenleri belirlenmiştir (Kaya vd., 2012). Kahta'nın 10 km kuzeyinde yer alan Erikdere köyüne yetişmeden $1 \mathrm{~km}$ önce, yol yarmasında farklı seviyelerde görülen bu fosillerin, o dönemde görülen sel felaketleri ile ölen canlı kalıntıları olduğu düşünülmektedir (Fotoğraf 2). Konglomera tabakasının hemen altında dağınık, fakat fazla 
kemik fosilinin bir arada bulunması bu görüşü doğrulamaktadır.

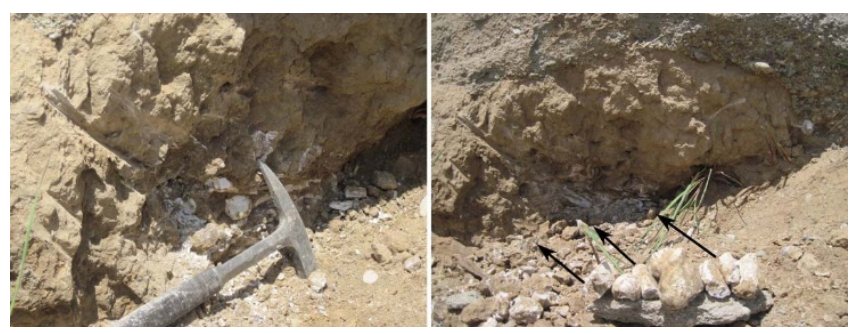

Fotoğraf 2. Erikdere köyü kuzeyinde konglomera tabakaları altında bulunan omurgalı fosilleri.

Photo 2. The vertebrate fossils that have been found under the layers of conglomerate in the north of Erikdere Village.

Yarlıca Dağı kuzeydoğusunda kireçtaşı arakatkılı marn ve kumtaşı ardalanması, diğer alanlardaki karasal ortam ürünlerinden farklılık göstermektedir. Bu özelliği nedeniyle, bu alandaki birimler denizel ortam ürünü Şelmo Formasyonu olarak yorumlanmıştır (Meriç, 1965; Günay, 1998).

\section{Pliyo-Kuvaterner}

$\mathrm{Bu}$ birim, inceleme alanında Kahta Çayı Vadisi'nin iki yakasında ve Kahta yerleşmesinin kurulduğu alanda, Şelmo Formasyonu'nun üzerinde adacıklar halinde görülmektedir (Şekil 2). Pliyo-Kuvaterner dolguları kırıntılı sedimentlerden oluşmaktadır. Genelde iri çakılların bulunduğu konglomera, ince kum ve silt boyutunda ince malzemenin karışımından oluşmaktadır. Bazı alanlarda iri çakıllar tarımı olumsuz etkilemektedir. Kahta Çayı Vadisi'nin çevresinde PliyoKuvaterner dolgularının adalar halinde görülmesi, şiddetli erozyon sonrasında ortaya çıkmış bir durumdur.

İnceleme alanında görülen Pliyo-Kuvaterner birimleri, oluşumlarından sonra meydana gelen dikey yükselmeler sonucunda 700-800 m yükseltilerine kadar çıkmıştır. Oldukça deforme olmuş bu birim, havzada genelinde ortalama 20-40 m arasında değişen kalınlığa sahiptir. Karadoğan (2005), bu birimin kalınlığının güneye doğru artmakta olduğunu ve bu durum üzerinde sediment kaynağının kuzeydeki yüksek eğimli alanlar olduğunu belirtmiştir.

\section{Kuvaterner}

Kahta Çayı Aşağı Havzası'nda Kuvaterner döneminde oluşan birimler, dağlık alanların dik yamaçları önünde gelişen kolüvyal depolar, Kahta Çayı Vadi tabanında biriken güncel dolgular ve Kahta Çayı taraça dolgularından oluşmaktadır (Şekil 2). Kahta Çayı Vadisi boyunca taraça dolguları, Yarlıca Dağı kuzeyindeki havzadan başlayıp, Kahta Çayı'nın Atatürk Baraj Gölü'ne döküldüğü alana kadar, Kahta Vadisi boyunca yer yer kalınlığı 60 m'yi bulan geniş dolgular halinde görülmektedir. Bu dolguların en yüksekte yer alanları genelde karbonat bir çimento ile birleşerek, sert konglomera depolarını oluşturmuştur. İkinci yüksek dolgular da demir ve magnezyum gibi minareller ile bağlanmış iyi sıkışmış depolardan oluşmaktadır. $\mathrm{Bu}$ dolguların alt bölümleri de kısmen gevşek ve ince kumlardan oluşan merceksi çapraz tabakalanma görülmektedir. Bu dolgular hem şiddetli erozyon hem de kum ocağı işletmeleri tarafından aşırı tahrip edilmiştir.

En genç Kuvatener birimleri, genişliği yer yer 1 km'yi bulan vadi tabanındaki alüvyonlardan oluşmaktadır. Yukarı havzada yaşanan şiddetli erozyon nedeniyle yağışlı dönemde, aşırı sediment taşınmakta ve bu malzeme vadi tabanında biriktirilmektedir. Vadi tabanında biriken malzeme, kum ocakları tarafından aşırı işletilmesine rağmen, Kahta Çayı'nın baraja döküldüğü alanda fazla alüvyon birikmektedir. Yaşanan bu olay sonucunda Atatürk Baraj Gölü'nün Kahta Çayı Vadisi boyunca yapmış olduğu girinti hızla doldurulmaktadır (Fotoğraf 3). Bu olay, sedimantolojik açıdan siltasyona, jeomorfolojik süreç olarak da kıyılarda görülen alüvyal boğulmaya karşılık gelmektedir. Alüvyal boğulma, Deniz seviyesinin yükselmesi sonucunda, kıyıdaki vadilerin ağız kısımlarının önce sular altında kalması, daha sonra bu girintilerin alüvyonlarla dolmasıyla oluşmaktadır (Erinç, 1996). Kahta Çayı́nın baraja döküldüğü alandaki oluşum da buna benzediği için alüvyal boğulma olarak değerlendirilmiştir.
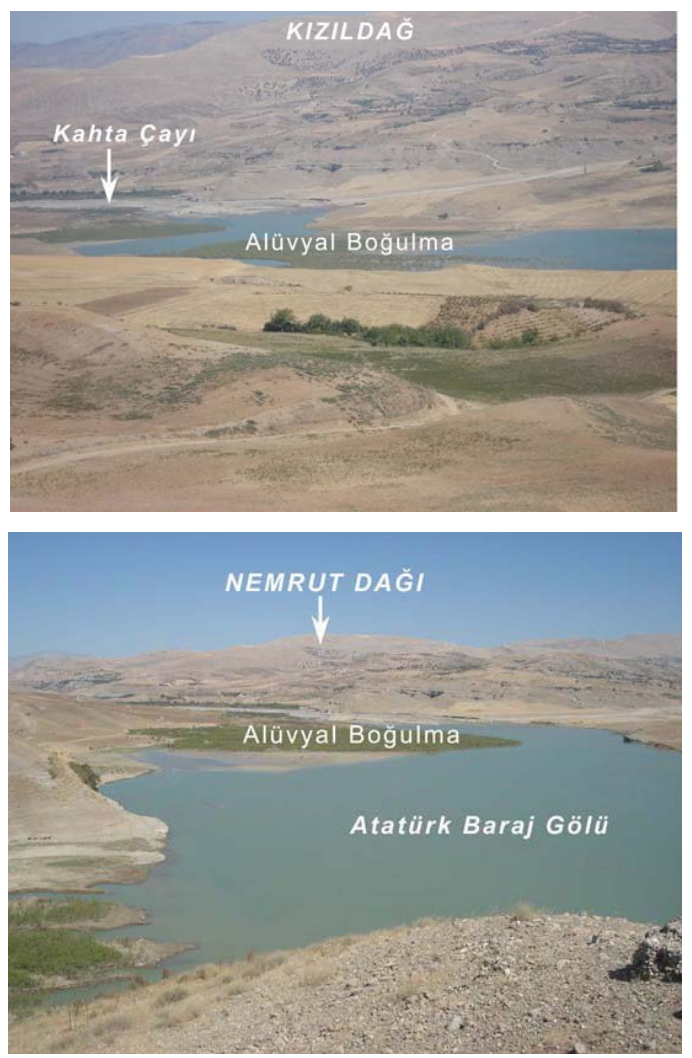

Fotoğraf 3. Kahta Çayı'nın Atatürk Baraj Gölü'ne döküldüğü alanda çok hızlı bir alüvyal boğulma yaşanmaktadır.

Photo 3. There occurs a rapid alluvial drowning in the area where Kahta Stream flows into the reservoir of Atatürk Dam.

\section{Sahanın Tektonik Özellikleri}

İnceleme alanı tektonik açıdan karmaşık ve oldukça hareketli bir konumda yer almaktadır. Kıvrımlı, kırıklı ve bindirmeli yapılar ana tektonik yapıları oluşturmaktadır (Şekil 3). Kahta Çayı Havzası bütünüyle DAFZ, Güneydoğu Anado- 
lu Bindirmesi (GDAB) ve Adıyaman Fay Zonu üzerinde yer almaktadır. DAF'ın etkisi yukarı havzada belirgin olup, inceleme alanı dışında kalmaktadır.

Havzada, KD-GB doğrultusunda uzanan antiklinal ve senklinaller, aynı doğrultuda uzanan normal, ters ve sol yanal doğrultu atımlı faylar gelişmiştir. Aynı zamanda bunları dikine kesen KB-GD doğrultulu bindirme ve ters faylar ile sağ yanal doğrultu atımlı faylar görülmektedir (Şekil 3).

\section{Kırımlı yapılar}

Çoğu ters faylarla sınırlandırılmış Kenar Kıvrımları Kuşağı'nda yer alan inceleme alanında, en önemli Tersiyer antiklinalleri Yarlıca (Halof) ve Karakuş antiklinalleridir (Öğrenmiş, 2006; Şekil 3). TPAO çalışanları Yarlıca ve Karakuş antiklinalleri dışında, Karakuş Antiklinali kuzey ve güneyinde de antiklinal ve senklinal yapıları gözlemlemişlerdir.

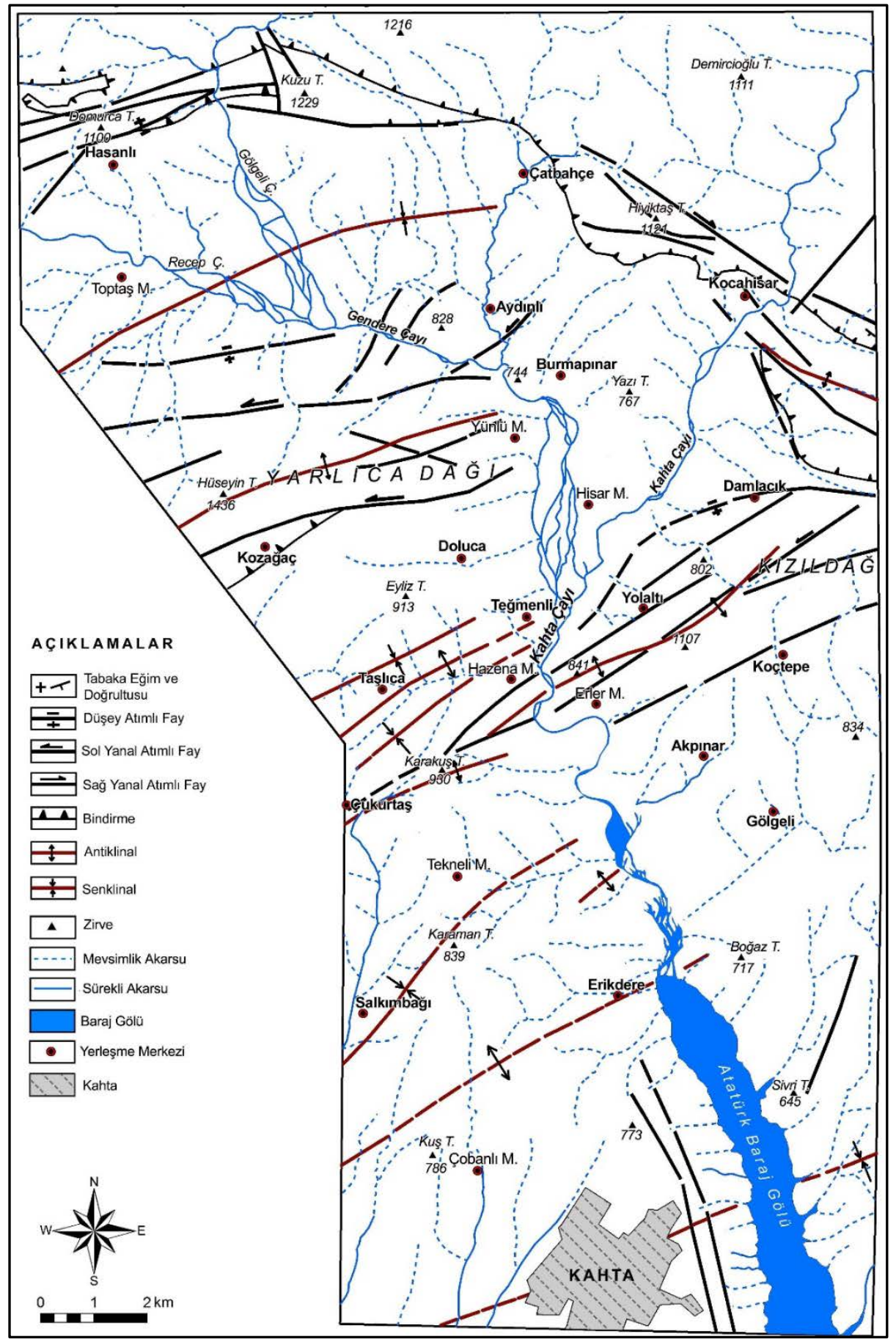

Şekil 3. Kahta Çayı Aşağı Havzası'nın(Adıyaman) tektonik haritası (Sungurlu ve diğ., (1991)'den değiştirilerek hazırlanmıştır).

Figure 3. The tectonic map of the Lower Kahta Stream (Adıyaman) Basin (It was prepared after modification, Sungurlu et al., 1991). 
Yarlıca (Halof) Antiklinali; Yarlıca Dağı'nı oluşturmakta olup, KD-GB doğrultusunda uzanmaktadır (Fotoğraf 4). Güneydoğuya eğimli kanadında eğim açıları 40'ye, kuzeybatıya eğimli kanatta $10-15^{\circ}$ ye çıkmaktadır (Şekil 3).
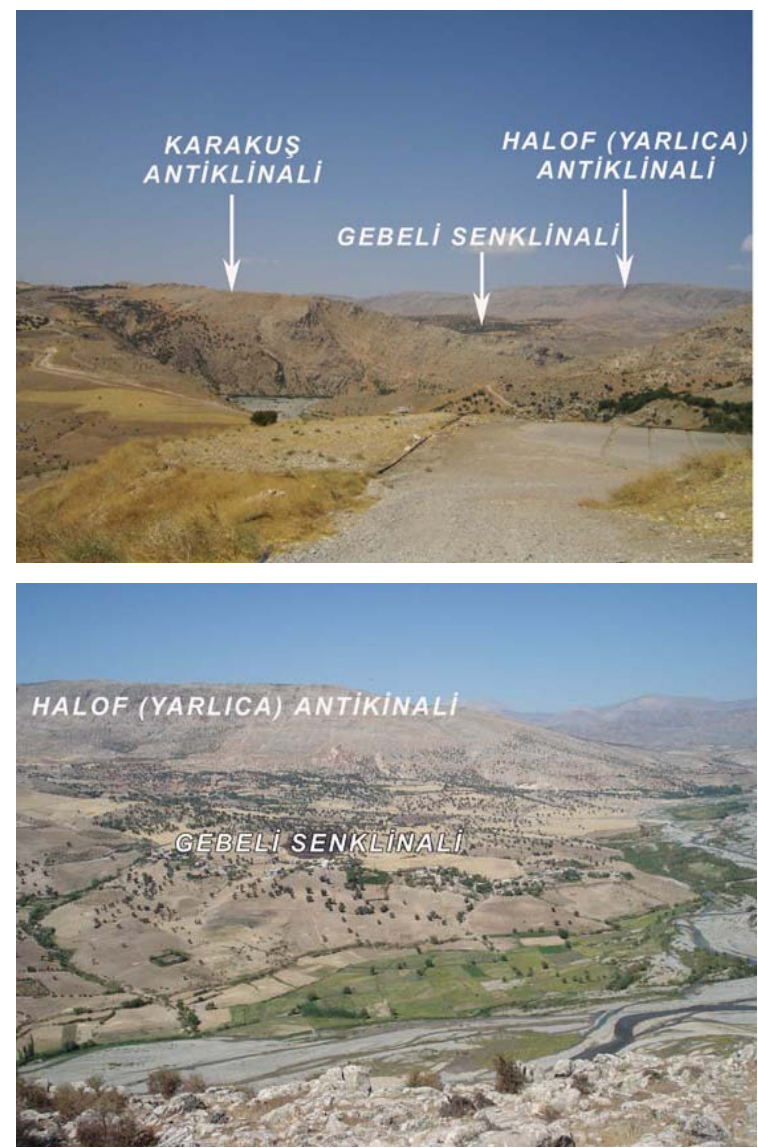

Fotoğraf 4. Yarlıca (Halof) ve Karakuş antiklinalleri ile Gebeli senklinali.

Photo 4. Yarlıca and Karakuş anticlinals with Gebeli syncline.

Karakuş Antiklinali: Yarlıca Dağı güneyinde, Yarlıca Antiklinali gibi Hoya Formasyonu içerisinde gelişmiş olup KD-GB doğrultusunda uzamaktadır (Fotoğraf 5). Antiklinalin eğimi kuzeybatı kanadında $40-45^{\circ}$, güneydoğu kanadında ise $35^{\circ}$ kadardır (Şekil 2).

Alikan Senklinali: Yarlıca Antiklinali kuzeyinde yer alan bu senklinal, Halof Antiklinali ile aynı doğrultuda uzamakta olup, doğu bölümünde bükülme eğilimi göstermektedir. Senklinal kanatlarında eğim 5-10 'llik düşük değerler göstermektedir.

Gebeli Senklinali: Halof ve Karakuş antiklinalleri arasında yer alan bu kıvrımlı yapı, antiklinallerin doğrultusuna uyumlu olup, kanatlarda eğim $5-10^{\circ}$ arasında değişmektedir (Fotoğraf 4).

Kahta Senklinali: Kahta ilçe merkezinden geçen bu senklinalin doğrultusu da diğer kıvrım doğrultularına paralel olup, kanatlarda eğim $2-3^{\circ}$ arasında oldukça düşük değerler göstermektedir (Şekil 3).
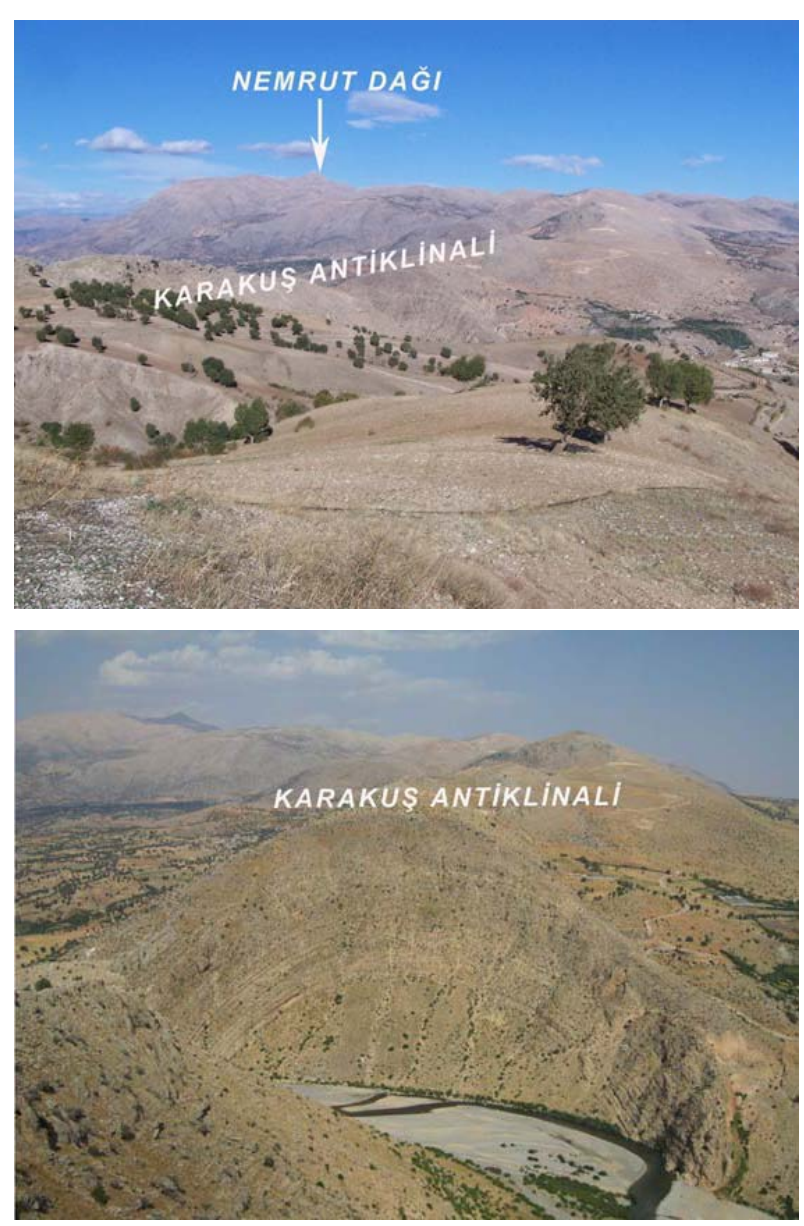

Fotoğraf 5. Yarlıca Dağı güneyinde yer alan Karakuş antiklinali. Karakuş Antiklinali Kahta Çayı tarafından kesilerek çok tipik klüz oluşmuştur.

Photo 5. Karakuş anticlinal located in the east of Mount Yarlıca. Karakuş Anticlinal has become a typical canyon as having been intersected by Kahta Stream.

\section{Kırıklı yapılar}

Havzanın kuzeyinde bindirme yapıları dışında KD-GB doğrultulu sol yanal ve eğim atımlı faylar ile KB-GD doğrultulu sağ yanal atımlı faylar görülmektedir (Şekil 3). KD-GB doğrultulu sol yanal atımlı faylar, Adıyaman Fay Zonu (AFZ) içerisinde yer almaktadır. DAF'ın $R$ kırığı (ikincil yapı) şeklinde görülen bu fay zonu, Palu ilçesinin batısında, DAFZ'ndan ayrılarak, güneybatıya döner, Hazar Gölü'nün güneyinde yer alan Helindir ve Hazar yerleşim birimleri içinden geçerek Adıyaman'a doğru devam etmektedir. Bu fay yaklaşık $3 \mathrm{~km}$ genişliğinde, $210 \mathrm{~km}$ uzunluğunda $\mathrm{K} 60^{\circ} \mathrm{D}$ doğrultulu, sol yanal atımlı bir fay zonudur. Kuzeydoğuda Palu, güneybatıda Besni (Adıyaman) arasında yer alan AFZ, paralel ve yarıparalel bir dizi fay segmentlerinden oluşmaktadır. Fırat Vadisi'ni sol yanal olarak öteledikten sonra, Adıyaman il merkezinden geçerek, Besni güneyinde çatallanıp kaybolmaktadır (Perinçek vd., 1987; İnceöz vd., 2003; İnceöz ve Zengin, 2014).

İnceleme alanının kuzeybatısında Hasanlı yerleşmesinin bulunduğu alan, eğim atımlı faylarla kesilerek yükselmiştir. Yarlıca Dağı kuzey yamaçları sol yanal atımlı faylarla kesilmiş ve bu alandaki mevsimlik akarsular sol yanal ötel- 
enmiştir. Bu dağın güney yamaçları da bindirme bileşenli sol yanal atımlı faylarla kesilmiştir. Bu şekilde kuzey ve güneyden faylarla sınırlandırılan Yarlıca Dağı, yükselerek kuzeye doğru çarpılmıştır.

Sol yanal atımlı fayların belirgin olduğu diğer bir alan YarIıca Dağı güneyinde yer alan Kızıldağ ve Nemrut Dağı yamaçlarıdır. Karakuş Antiklinali'nden sonra belirgin olarak gözlenen bu fay Öğrenmiş (2006) tarafından Hopak Fayı olarak adlandırılmıştır. Kızıldağ'ın kuzey yamaçları bu fay tarafından kesilerek parçalanmıştır (Fotoğraf 6). Damlacık Yolaltı arasında çok belirgin olan fay, bu alanda heyelanlı bölgenin oluşmasına neden olmuştur. Aynı şekilde Kızıldağ'ın güney yamaçları da faylarla kesilmiştir. Bu faylı yapılara bağlı olarak hem Yarlıca, hem de Kızıldağ adeta bir horst gibi yükselmiştir. Havzanın kuzeydoğusunda ise KBGD doğrultulu sağ yanal atımlı fayların hareketi sonucu, Kocahisar doğusunda Kahta Çayı 250-500 m kadar sağ yanal ötelenmiştir.
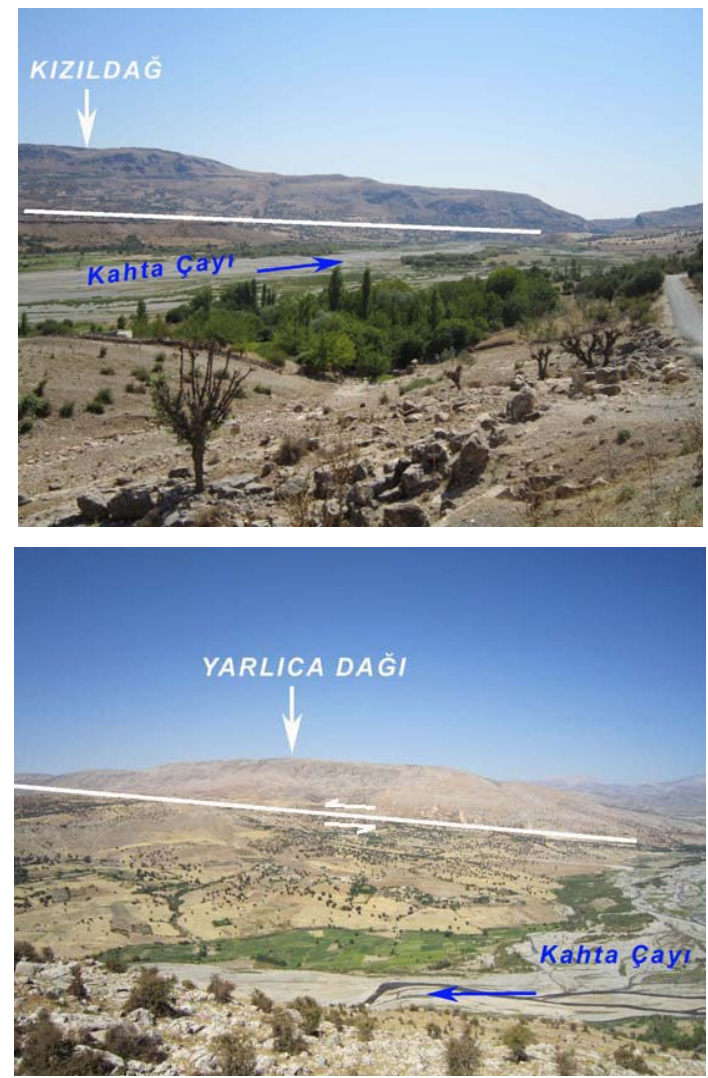

Fotoğraf 6. Kızıldağ ve Yarlıca Dağı'nı kesen faylı yapılar.

Photo 6. Faulted structures that intersect Kızıldağ and Mount Yarlıca.

Inceleme alanında doğrultu atımlı faylar 3 noktada dikkat çekmektedir. Bunlardan birincisi, Damlacık üzerinden gelip Yarlıca Dağı güney yamaçlarından devam eden faydır. Bu fay için Yarlıca Fayı adı önerilmektedir. İkincisi, Nemrut ve Kızıldağ kuzey yamaçlarından gelip güneybatıya devam eden faydır. Bu fay için de Nemrut Fayı, Kocahisar kuzeydoğusundan geçen ve bu faylara ters doğrultuda olan fay için ise Kocahisar Fayı adı uygun görülmüştür (Karataş, 2012).

\section{Bindirme yapıları}

Kahta Çayı Aşağı Havzası içerisinde kalan doğrultu atımlı fayların bir bölümü bindirme bileşenlidir. K-G yönlü sıkışmanın devam etmesine bağı olarak bindirmelerin bir bölümü doğrultu atım kazanmıştır.

Inceleme alanında yer alan en önemli bindirme, Koçali Karmaşığı ile Şelmo Formasyonu arasında yer alan Recep Bindirmesi'dir. Kuzeybatı doğrultulu olan Tersiyer yaşlı Recep Bindirmesi ile Koçali Karmaşığı, Şelmo Formasyonu'nun Eski Kahta Üyesi'ni tektonik olarak üzerlemektedir. Bindirme cephesinin önündeki kıvrımlarda, Eski Kahta Üyesi'nin tabaka eğimleri, kuzeydoğuya eğimli kanatlarda $45^{\circ}-55^{\circ}$ iken güneybatıya eğimli kanatlarda $70-75^{\circ}$ ye çıkmaktadır. Recep Bindirmesi dışında Yarlıca Dağı güney yamaçlarında görülen bindirme Yarlıca (Halof) Bindirmesi'ni oluşturmaktadır. Bu bindirme D-B doğrultulu görünse de antiklinalin genel uzanışına paralel bir gidiş göstermektedir. Faylanmanın olduğu bindirme hattında $50^{\circ}-70^{\circ}$ lik devrik tabakalar bulunmaktadır (Öğrenmiş, 2006).

\section{ÇALIŞMA ALANININ JEOMORFOLOJiK ÖZELLIKLERI}

Kahta Çayı Aşağı Havzası'nın kuzey bölümü, Güneydoğu Toroslar'ın güneyinde yer alan Kenar Kıvrımları kuşağında, güney bölümü Adıyaman Havzası üzerinde yer almaktadır. Kahta Çayı Havzası, bütünüyle tektonik açıdan oldukça hareketli ve genç bir kuşak üzerinde bulunmaktadır. Bu konumu nedeniyle, yerşekillerinin oluşum ve gelişiminde yapısal özellikler birinci derecede etkili olmuştur. Tektonik hareketler sonucu oluşan şekiller, flüviyal süreçlerle deforme olarak farklı yer şekilleri ortaya çıkmıştır. Kahta Çayı Vadisi, bu sürece bağlı oluşan en önemli jeomorfolojik birimdir.

Kahta Çayı Aşağı Havzası'ndaki ana jeomorfolojik birimler, kuzeydeki dağıık alanlar ve bu dağlık alanlar üzerindeki yüksek platolar, güneyde Adıyaman Havzası'na karşılık gelen alçak platolar ve Kahta Çayı Vadisi'nden oluşmaktadır (Şekil 4). İnceleme alanının kuzeyinde 800 m yükseltisinden başlayıp, 1500 m'ye kadar çıkan dağlık alanlar ve bu dağlık alanların üzerinde yüksek platolar yer almaktadır. Güneyde 600-800 m yükseltileri arasında, güneye doğru eğimli havza tabanına karşılı gelen alçak platolar bulunmaktadır. Bu platolardan vadi tabanlarına geçişte farklı yükseltilerde akarsu taraçaları görülmektedir. Kuzeyde dağlık alanlar üzerinde kıvrımlı ve kırıklı yapıda gelişen yer şekilleri oluşmuştur. Kahta Çayı'nın antiklinalleri kestiği yerlerde klüzler, fay diklikleri üzerinde meydana gelen kütle hareketleri, karstik alanlardaki karstik şekiller ve taraçalar en dikkat çekici jeomorfolojik birimleri oluşturmaktadır (Şekil 4).

\section{Jeomorfolojik Birimler}

Kahta Çayı Aşağı Havzası'nda yer alan taraçalar, jeomorfolojik birimler arasında önemli bir yere sahiptir. Kahta Çayı 


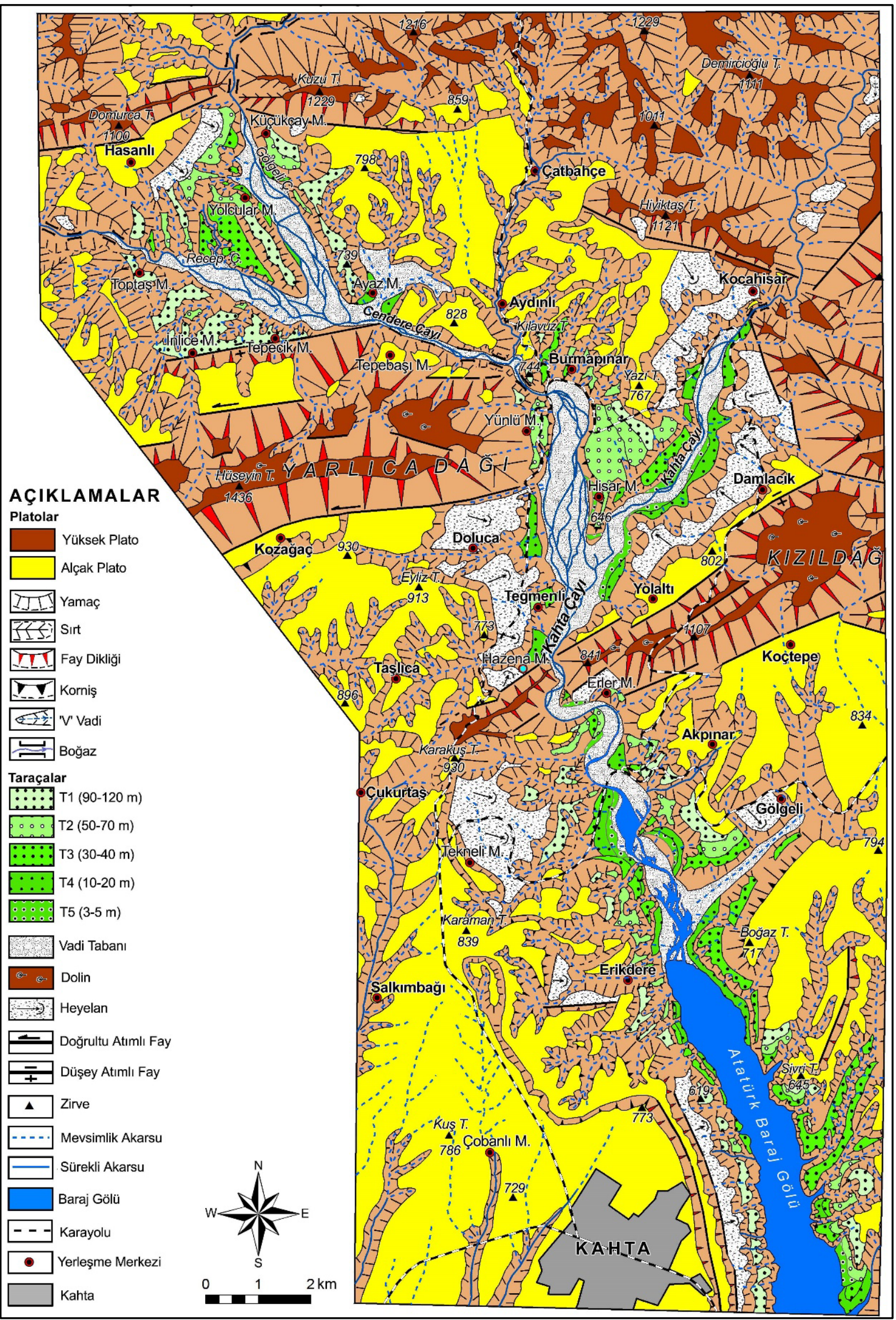

Şekil 4. Kahta Çayı Aşağı Havzası'nın (Adıyaman) jeomorfoloji haritası (Sunkar ve Karataş, 2012a; Karataş, 2012).

Figure 4. The geomorphologic map of the Lower Kahta Stream (Adıyaman) Basin (Sunkar and Karataş, 2012a; Karataş, 2012). 
taraçalarının jeomorfolojik özellikleri, başka bir çalışmada detaylı bir şekilde açıklanması düşünüldüğünden, bu çalışmada sadece genel özellikleri verilmiştir. Taraçalar dışındaki jeomorfolojik birimler ise detaylı değerlendirilmiştir.

\section{Dağlık alanlar}

Kahta Çayı Aşağı Havzası'nın kuzeyindeki dağlık alanlar, KD-GB doğrultusunda uzamakta olup, Güneydoğu Toroslar'ın güney bölümündeki kuşağı oluşturmaktadır. Bölgenin genel orografik yapısına paralel olan bu dağlık alanlar, bölgede Alp orojenezinin gelişimi ile paralel olup kıvrımlı, kırıklı ve bindirmeli bir yapı özelliği göstermektedir. KD-GB doğrultusunda uzanan kıvrımlar KD-GB ve KBGD doğrultusunda faylarla kesilmiştir. Dağlık alanların yapısı, en kuzeyde Jura-Kretase döneminde oluşan Koçali Karmaşığı, bunun güneyinde Alt Eosen-Oligosen kireçtaşlarından oluşmaktadır (Şekil, 2, 3).

Adıyaman Havzası'nı kuzeyden sınırlandıran Kızıldağ ve Nemrut Dağı ile bunun kuzeyindeki Yarlıca Dağı, aşağı havzadaki en önemli dağlık alanları oluşturmaktadır. Kızıldağ dışında, Nemrut Dağı'nın bazı zirveleri de inceleme alanı içerisinde kalmaktadır (Fotoğraf 5). Nemrut Dağı'nın batı devamını oluşturan Kızıldağ, ortalama $1100 \mathrm{~m}$ yükseltilerinde yer almakta olup, kireçtaşlarından oluşmaktadır. Bu yapı özelliği nedeniyle, dağın üzerinde karstik şekillerden dolinler gelişmiştir. Kuzey ve güney yamaçları faylı olan, bu dağlık alan önemli petrol rezervine sahiptir. Kuzey yamaçlarında faylanma etkisiyle geniş alanlı heyelanlar oluşmuştur.

Bölgeyi işgal eden Eosen ve Miyosen denizleri canlı ortamı yönünden zengin olup denizel ortamda bol miktarda canlı yaşamıştır. Bu denizel ortamdaki tortulların yavaş kıvrılması ile antiklinaller oluşmuş ve burada canlı kalıntılarının yağa dönüşmesi ile petrol yatakları oluşmuştur (Fotoğraf 7). Güneydoğu Anadolu'nun alçalmaya uğraması ve Toros Dağları'nın yükselmesi, dağ ile ova arasında 2000 m'yi aşan bir yükseklik farkı oluşturmuştur. Bu nedenle yüksek sahalar, akarsular tarafından güneydeki alçak düzlüklerin seviyesine göre yarılarak, dar ve derin vadiler açılmış ve son derece engebeli bir topografya ortaya çıkmıştır (Atalay vd., 2002).
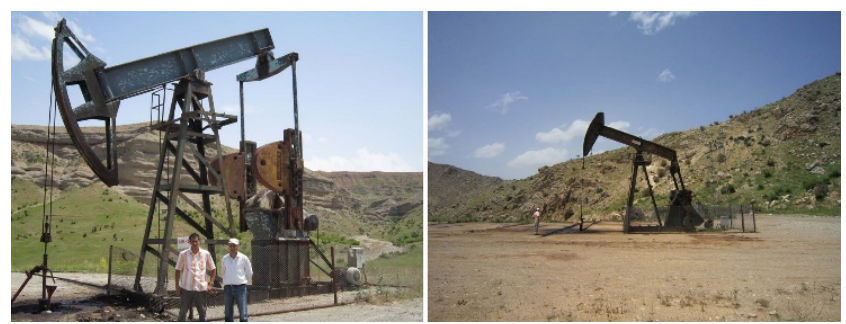

Fotoğraf 7. Kahta kuzeyindeki petrol sahasında işletilmekte olan petrol kuyuları.

Photo 7. Oil wells that are being run in the oil field in the north of Kahta.
Yarlıca (Halof) Dağı da inceleme alanındaki diğer dağlar gibi KD-GB doğrultusunda uzamakta olup, antiklinal yapısı göstermektedir. Dağın en yüksek zirvesini Hüseyin Tepe $(1436 \mathrm{~m})$ oluşturmaktadır. Karstik yapısı nedeniyle üzerindeki düzlüklerde dolinler gelişmiştir. Kuzey ve güney yamaçları faylarla kesilerek yükselmiş ve kuzeye doğru çarpılmıştır (Fotoğraf 4, 6). Güney yamaçlar faylanmaya bağlı olarak eğim değeri yüksek fay dikliklerinden oluşmaktadır. Doğu bölümü ise Cendere Çayı tarafından yarılmıştır.

\section{Yüksek platolar}

İnceleme alanında dağlık alanlar üzerinde 900-1300 m yükseltileri arasında bir bölümü aşınım yüzeyi karakterinde olan geniş düzlükler yer almaktadır. Yükseltilerine göre bu düzlükler yüksek platolar olarak haritalanmıştır. Karadoğan (2005) Erol sistemini (1983) dikkate alarak, Adıyaman Havzası'nın kuzeyinde 1350-1500 m yükseltileri arasındaki düzlükleri Alt-Orta Miyosen (DI Sistemleri), 1150-1350 m yükseltileri arasındaki düzlükleri Üst Miyosen (DII Sistemleri) olarak haritalamıştır. Bu ayrıma göre inceleme alanındaki yüksek platolar Erol yöntemine (1983) göre DI ve DII sistemleri içinde kalmaktadır.

En kuzeydeki dağlık alanlar üzerinde yer alan düzlükler ile Yarlıca ve Kızıldağ üzerindeki düzlükler farklı özellikler göstermektedir. Bu düzlükler, kuzeyde Koçali Karmaşığı'nın görüldüğü alanlarda dar alanlı, diğer dağlık alanlar üzerinde ise daha geniş alanlıdır. Bu özellik doğrudan litolojik yapı ile ilgili bir durumdur.

\section{A/çak platolar}

İnceleme alanında 650-850 m yükseltileri arasında kalan düzlükler alçak plato olarak haritalanmıştır. Bu platolar kuzeyde tektoniğin etkisiyle 900 m'ye kadar çıkmaktadır. Büyük bölümü Üst Miyosen-Pliyosen birimleri üzerinde görülen bu düzlükler Yarlıca Dağı kuzey ve güneyinde senklinal havzalarında, Kızıldağ güneyinde ise Adıyaman Havza tabanına karşılık gelmektedir. Kahta Çayı ve kolları tarafından 150-200 m kadar yarılmış olan bu düzlükler tektonik hareketlerden etkilenerek güneye doğru çarpılmıştır. Dağlık alanların eteklerinde yer alan eğimli düzlükler ile havza tabanını oluşturan düzlükler bu plato grubu içinde değerlendirilmiştir (Şekil, 4). İnceleme alanındaki alçak platolar, Karadoğan'ın (2005) Adıyaman Havzası için önerdiği 9501150 m yükseltileri arasındaki DIII sistemleri ile 600-900 m yükseltilerindeki DIV sistemlerini kapsamaktadır.

Bölgesel ve yerel tektonik hareketlerle oldukça deforme olan düzlük sistemlerini birbirinden ayırmak oldukça güçtür. Bu nedenle Kahta Çayı Aşağı Havzası'nda DI ve DII ile DIII ve DIV sistemleri iç içe geçmiştir. Platoları oluşturan düzlüklerin bu durumu dikkate alınarak yüksek ve alçak platolar olarak ayrılmıştır (Şekil 4; Fotoğraf 8).

Alçak platolar, inceleme alanında önemli tarımsal arazileri oluşturmakta olup, tahıl tarımı yapılmaktadır. Bu platolar tektonik ve litolojik yapıya bağlı olarak Kahta Çayı doğusunda fazla, batısında az parçalanmıştır. 

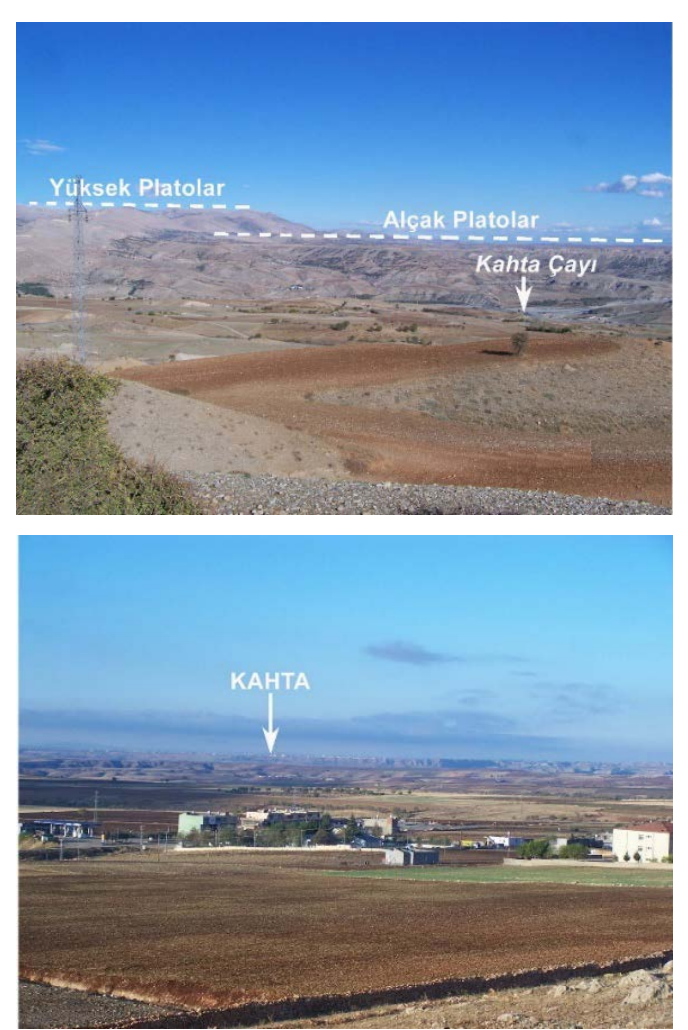

Fotoğraf 8. Kahta kuzeyinde dağlık alanlar ile havza tabanında oluşan yüksek ve alçak platolar.

Photo 8. The mountainous areas in the north Kahta and high and low plateaus existing in the basin's ground.

\section{Havzalar}

Kahta Çayı Havzası, Güneydoğu Toroslar üzerinde yer almasına rağmen bazı bölümlerinde senklinal havzalar yer almaktadır. Yarlıca Dağı kuzey ve güneyinde yer alan havzalar bunların en önemlileridir. Yarlıca Dağı kuzeyinde yer alan ve Alikan Senklinali'ne karşılık gelen alan, bu çalışmada Alikan Havzası olarak adlandırılmıştır. Ortalama 750 m yükseltisinde yer alan havza elips şeklindedir. Dağlık alanlarla çevrelenmiş olan bu havzadan güneydeki havzaya geçişte az belirgin bir eşik saha yer almaktadır. Havza, kuzey ve güneyden faylarla sınırlandırılmıştır. Havzaya kuzeyden bağlanan Gölgeli ve batıdan bağlanan Recep çayları havzada birleşerek Cendere Çayı'nı oluşturmaktadır. Akarsular tarafından $100 \mathrm{~m}$ kadar yarılmış olan havza dolguları güneye doğru $10-20^{\circ}$ eğimlenmiştir.

Yarlıca Dağı ile Kızıldağ arasında yer alan ve Gebeli Senklinali'ne karşılık gelen alan, tarafımızdan Gebeli Havzası olarak adlandırılmıştır. Bu havza, ortalama $650 \mathrm{~m}$ yükseltilerinde yer almakta olup üçgen şeklindedir. Dağlık alanlarla çevrelenmiş olan havza, kuzey ve güneydeki havzalara boğazlarla bağlanmaktadır. Üçgen şekli almasında havzayı sınırlandıran faylar etkili olmuştur. Bu havzada da kuzeyden gelen Cendere ve doğudan gelen Kahta çayları birleşerek ası Kahta Çayı'nı oluşturmaktadır. Bu iki büyük çayın birleşme alanında kalın ve yaygın taraça dolguları birikmiştir (Şekil 4).

Kızıldağ güneyinde kalan inceleme alanı Adıyaman Havzası içerisinde yer almaktadır. Adıyaman Havzası,
Güneydoğu Anadolu Bölgesi'nin Orta Fırat Bölümü'nde, kuzeyde Güneydoğu Toroslar, güneyde Atatürk Baraj Gölü arasında yer almaktadır. Bu havza Neojen birimleri ile örtülü olup Kahta, Ziyaret ve Göksu çayları tarafından yarılmıştır. Ortalama 600-700 m yükseltileri arasında yer alan havza tabanı, kuzeyden güneye doğru 2-3 eğimli olup Kahta kuzeyinde eğimi ve yarılma değeri artmaktadır. (Karadoğan, 2005; Karadoğan ve Tonbul, 2013).

\section{Vadiler}

Kahta Çayı Havzası'ndaki vadiler, tektonik ve litolojik özellikler ile iklimin etkisinde gelişmiştir. Kahta Çayı Vadisi, bölgenin genel tektonik yapısına uyumsuz bir gelişim göstermektedir. Çünkü KD-GB doğrultulu kıvrımlı yapılar, K$G$ doğrultusunda akarsular tarafından yarılarak dar derin boğazlar oluşmuştur. Fakat yan kollar önemli ölçüde tektonik hatlara uyum göstermektedir.

Kahta Çayı'nı oluşturan Recep ve Gölgeli çayları, Alikan Havzası'na birer boğazla açılmaktadır. Kıvrımlı ve kırıklı yüksek kütleleri kesen bu boğazlar antesedans oluşumludur. Alikan Havzası'nda bu akarsular geniş tabanlı örgülü drenaj özelliği göstermektedir. Havzada akarsu kolları hem Kuvaterner, hem de Üst Miyosen birimlerini yarmıştır. Alikan Havzası'nda birleşen bu kollar Cendere Çayı'nı oluşturmaktadır. Cendere Çayı da Yarlıca Dağı doğusunda antiklinalin alçalan bölümünü kesmekte olan Cendere Boğazı'nı oluşturmuştur (Karataş, 2012).

Cendere Çayı, Cendere Boğazı çıkışında ikinci bir senklinal havza olan Gebeli Havzası'na geçmektedir. Cendere Çayı, bu havzanın güneyinde doğudan gelen Kahta Çayı ile birleşerek asıl Kahta Çayı'nı oluşturmaktadır. Kahta Çayı, Gebeli Senklinali güneyinde antiklinal yapısı gösteren Kızıldağ'ın batıya doğru alçalan bölümü üzerinde açmış olduğu Küsuh Boğazı ile Adıyaman Havzası'na açılmaktadır. Kahta Çayı Vadisi, Cendere Boğazı ile Küsuh Boğazı arasında oldukça geniş yataklı olgun bir vadi özelliği göstermektedir. Bu alanda Kahta Çayı taban genişliği bazı alanlarda 1 km'yi bulan vadi tabanında örgülü drenaj ağı oluşturmaktadır (Fotoğraf 9 a, b). Erinç ve Bilgin (1956) bu alanın Türkiye'de tipik örgülü drenajın görüldüğü önemli alanlardan biri olduğunu belirtmiştir.

Kahta Çayı, Küsuh Boğazı ile Kahta Köprüsü arasında menderesli bir yapı özelliği göstermektedir (Fotoğraf $9 \mathrm{c}$, d). Karadoğan (2005) bu alandaki menderes yapısının Kahta Çayı'nın yapıya gömülmesi sonucunda oluştuğunu belirtmektedir. Bu oluşumun, Alt Pleyistosen'den önce düşük eğimli yatağında akan Kahta Çayı'nın menderesli yapısı ile açıklanmaktadır. Küsuh Boğazı'ndan sonra menderesli yapı bu görüşü desteklemektedir. Fakat, bu alanda menderesli yapının oluşumunda, antiklinalin kuzey ve güney yamaçlarını kesen fayların da etkili olduğu görülmüştür.

Kahta Çayı, Kahta Köprüsü'nden sonra baraj gölüne ulaşana kadar geniş vadi tabanında tipik örgülü drenaj ağına sahiptir. Yukarıda açıklandığı gibi Kahta Çayı aşağı havzada, havza tabanlarında örgülü, bu havzaları birleştiren 

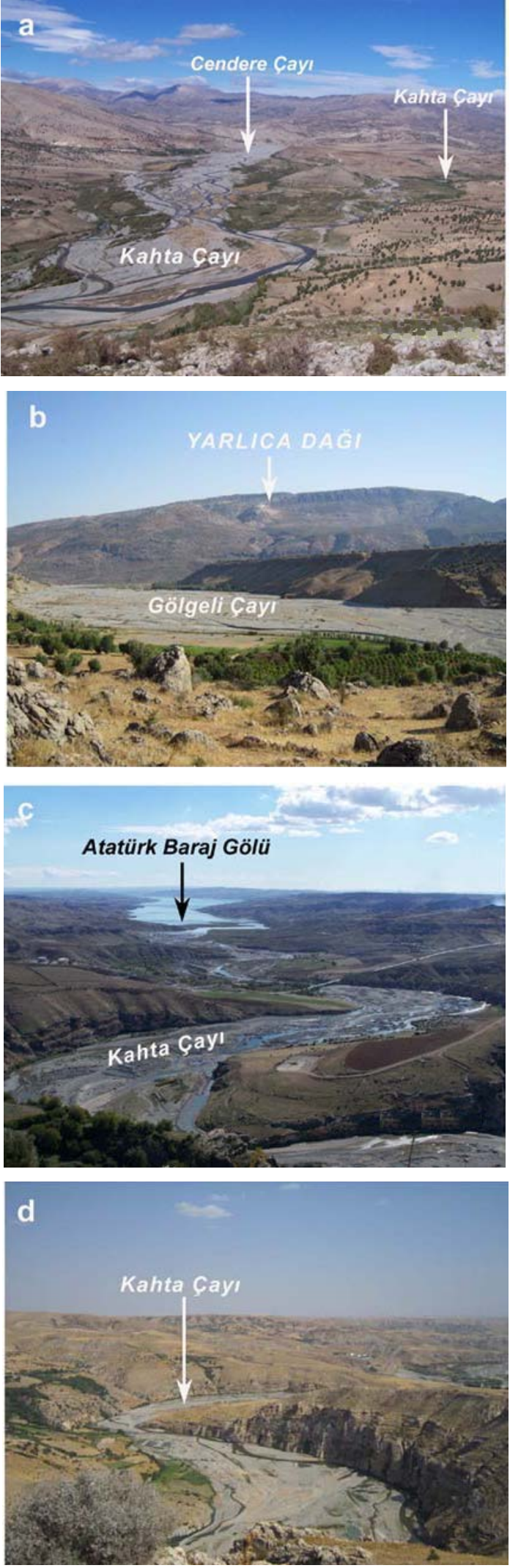

Fotoğraf 9. Kahta Çayı, Gebeli ve Alikan havzalarında örgülü $(a, b)$, diğer alanlarda geniş menderesli bir drenaj özelliği göstermektedir (c, d).

Photo 9. Kahta stream has a braided drainage feature (a, b) in Gebeli and Alikan basins and has a wide meandering drainage feature in other fields $(c, d)$. alanlarda dar derin yer yerde gömük menderesli bir yapı özelliği göstermektedir (Fotoğraf 9). Kahta Çayı Vadisi'nin Küsuh Boğazı kuzeyinde kalan bölümü, KD-GB doğrultulu, güneyinde kalan bölümü K-G doğrultulu faylar tarafından kesilmiştir. Kahta doğusunda vadinin doğu yamaçlarını kesen faylar vadinin derinleşmesini sağladığı gibi yamaçların basamaklanmasına neden olmuştur. Bu yamaçlarda, faylanma etkisiyle taraçalar deforme olmuştur. Kütle hareketlerinin yoğun olduğu bu yamaçlarda, taraçaları sınıflandırmak oldukça zordur.

Atatürk Baraj Gölü'nde su tutulmasıyla birlikte göl, Kahta Çayı Vadisi ile kuzeye doğru büyük bir girinti oluşturmuştur. Bu şekilde vadinin Adıyaman Havzası'nda kalan önemli bir bölümü sular altında kalmıştır. Baraj ile birlikte Kahta Çayı taban seviyesinde bir değişim yaşanmıştır. Çay bu değişime ayak uydurarak baraja döküldüğü alanda hızlı bir alüvyal boğulmaya yol açmaktadır (Fotoğraf 3).

\section{Boğazlar}

Kahta Çayı, Fırat sitemine dahil olduğu için bu sistemde görülen boğazların oluşumu ile Kahta Çayı Aşağı Havzası'nda yer alan boğazların oluşumu paralellik göstermektedir. Kahta Çayı Havzası da dahil olmak üzere Güneydoğu Toroslar üzerindeki boğazların oluşumu ile ilgili öne sürülen değişik görüşler bulunmaktadır.

Darkot (1943) Güneydoğu Toroslar alanında en dikkat çekici coğrafi olayın Fırat Boğazları olduğunu belirtmiş ve bu boğazların oluşumu ile ilgili üç ihtimal üzerinde durmuştur. Fırat Nehri'nin bu dağları yarıp geçtiği yerlerin dağ duvarının en dar ve en alçak sahası olmadığını, bu nedenle oluşumlarının merak uyandırdığı vurgulanmıştır.

1. Başlangıçta Fırat'ın yukarı kısmının suları, bu dağların gerisindeki gölde birikiyordu. Biriken sular uygun iklim şartları altında taşarak doğal yataklarını bulmuştur.

2. Aşağı Fırat vadisi, vadilerin gelişim sürecine uygun olarak, geriye aşınımla dağlar arasında kalan alanı kazıp yukarı havzayı kendine bağlamıştır.

3. Fırat Vadisi günümüzdeki yerine yerleştiği sırada henüz Güneydoğu Toroslar yükselmemişti. Toroslar yavaş yavaş yükselirken nehir de olduğu yerde araziye gömülmüştür.

Tanoğlu (1944), Malatya Havzası'nın bir dönem kapalı gölle işgal edildiği daha sonra bu gölün Fırat Nehri tarafından kapıldığını belirtmektedir. Fırat'ın havzanın kapıldığı yerde bariz bir dirsekle sert kayaçlar içerisinde açmış olduğu dar ve derin boğaza dikkat çekmiştir.

Erinç (1953) Güneydoğu Toroslar'ı yaran Fırat Nehri'nin oluşturduğu boğazın, oluşum mekanizması, açıklanması gereken önemli bir konu olarak görmüştür. Bu akarsuyun kıvrım eksenlerine, kontakt sahalarına, tektonik hatlara ve genç dislokasyon doğrultularına sıkı bir şekilde uyduğunu belirterek, yarma vadinin nisbi gençliğine dikkat çekerek, 
geriye aşındırma ile oluşabileceği intimali üzerinde durulmuştur.

Atalay (1994) Fırat'ın Kömürhan civarında ofiyolitik kütleye antesedans olarak saplandığını ve Malatya Havzası'nı kaparak havza dolgularını boşalttığını belirtmektedir. Özdemir ve Tonbul (1996) ise bu boğazın oluşumunun, çok dönemli birden fazla faktörün etkisinde gelişmiş bir antesedans boğaz olduğunu tespit etmişlerdir.

Erol ve diğerlerine (1987) göre, Üst Pliyosen'de havzalar akarsu çökelleri ile dolarken, alçalan kaide seviyesi nedeniyle yatağını derinleştiren bazı yerel akarsular geriye aşındırmalarla boğazları aşarak havzaları birbirine bağlamış, böylece Fırat Nehri doğmuştur. Pleyistosen başlarında gelişkin bir profile ulaşan Fırat Nehri, Pleyistosen sürecinde değişen iklim koşulları ve taban seviyeleri etkisi ile menderesleriyle birlikte olduğu gibi gömülmüş, özellikle dayanıklı kayaçlar içinde epijenik boğazlarını oluşturmuştur.

Karadoğan (2005), Karadoğan ve Tonbul (2013) ise Adıyaman Havzası kuzeyindeki kütleyi yaran boğazların bölgesel jeodinamik sürecin bir parçası olarak antesedan oluşumlu olduklarını belirtmiştir. Küsuh Boğazı'nın Pliyosen örtü birimleri içine gömülmesi ile epijenik, Kuvaterner'de yerel yükselmelere uyumlu olarak antesedans gelişim gösterdiği vurgulanmıştır.

Yukarıdaki değerlendirmelere göre, Fırat sistemindeki boğazlar oluşum bakımından karmaşık bir yapı göstermektedir. Kahta Çayı Aşağı Havzası'nın kuzeyindeki boğazlar antesedans, güneyindeki boğazlar ise epijenik oluşumludur. Son dönemdeki bölgesel ölçekli tektonik hareketlere bağlı olarak epijenik boğazlarda, antesedans oluşumun izleri de görülmektedir. Kıvrımlı yapıdaki Yarlıca Dağı ve Kızıldağ'ın kuzey ve güneyden faylarla kesilerek yükselmesi, boğazların oluşumunda antesadanslığın etkisini göstermektedir.

\section{Küsuh Boğazı}

Küsuh Boğazı, Adıyaman Havzası'ndan kuzeydeki dağlık alanlara geçişteki ilk boğazı oluşturmaktadır. Boğaz, kuzeydeki Gebeli Havzası ile güneyde Adıyaman Havzası arasında yer alan Kızıldağ Antiklinali'nin yarılmasıyla oluşmuştur (Fotoğraf 10). Doğu yamaçlarda kıvrımlı yapının çok belirgin olması, bu boğazın tipik bir klüz şeklinde oluştuğunu göstermektedir (Karadoğan, 2005; Karadoğan ve Tonbul, 2013). Eosen kireçtaşları içerisinde açılan boğazın derinliği 200-250 m arasında değişmektedir.

Karadoğan (2005), Küsuh Boğazı yamaçlarındaki asimetriyi, Pleyistosen başlarında menderesli akış gösteren Kahta Çayı'nın temele gömülmesinin bir sonucu olarak açıklamıştır. Boğaz çıkışında mendereslerin belirgin olması bu durumu doğrulamaktadır. Kahta Çayı'nın son dönemde boğaz içerisindeki gömülmesi ise antesedansa bağlanmıştır. Kısaca boğazın oluşumu epijenik olup sonraki dönemlerde tektonik yükselmelere ayak uydurarak günümüzdeki şeklini almıştır.
Kahta Çayı'nın Küsuh Boğazı içerisinde ve boğazın çıkışında gömük mendereslerden oluşması, epijenik yarılmayı göstermektedir. Bu morfolojik veri dışında, Adıyaman Havzası kuzeyinde Pliyo-Kuvaterner dolgularının boğazın olduğu sırtların yükseltisine çıkması, bu duruma delil oluşturmaktadır. Fakat, boğazın kuzey ve güney yamaçlarının faylı olması, boğazın oluşumunda epijenik ve antesedans olaylarının eş zamanlı olduğunu göstermektedir.
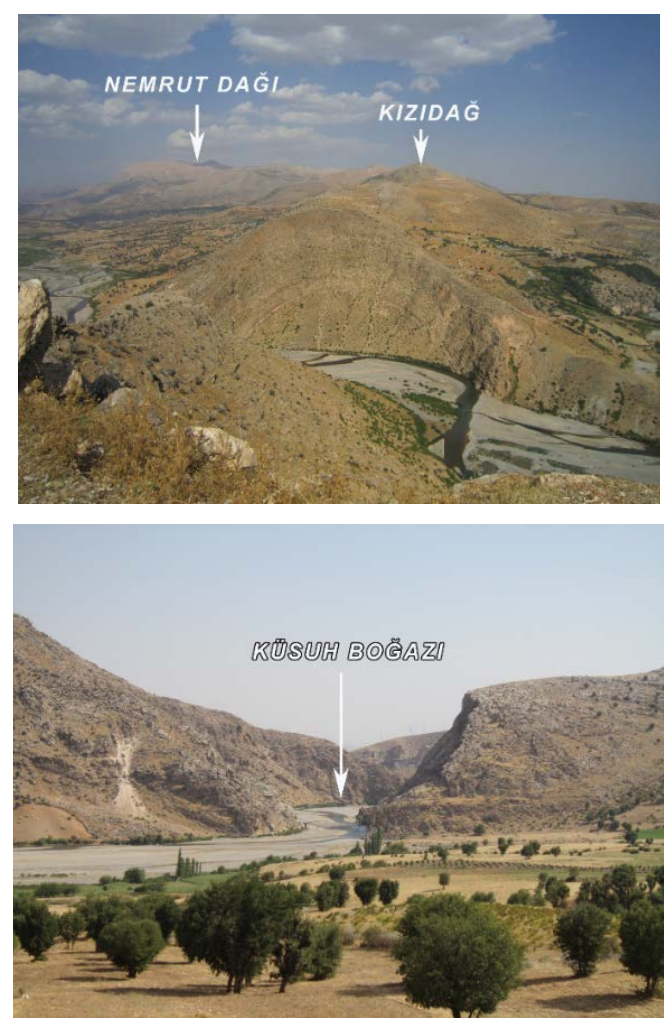

Fotoğraf 10. Kızıldağ'ın batıya doğru devamında yer alan ve antiklinal özelliği belirgin sırtların yarılmasıyla oluşmuş Küsuh Boğazı.

Photo 10. The Küsuh Strait located in the continuation of the west of Kızıldağ and which was formed by the cracks of hillsides with distinct anticlinal features.

\section{Cendere Boğazı}

Yarlıca Dağı doğusunda antiklinalin doğuya doğru alçaldığı alanda açılmış olan boğaz, Cendere Boğazı'nı oluşturmaktadır. Cendere Boğazı, kuzeydeki Alikan ile güneydeki Gebeli havzalarını birleştirmektedir. Yarlıca Dağı doğusunda Eosen kireçtaşları içerisinde KB-GD doğrultusunda açılmış boğaz, ortalama $200 \mathrm{~m}$ derinliğinde $3 \mathrm{~km}$ uzunluğundadır (Fotoğraf 11).

Cendere Boğazı'nın oluşumu karmaşık ve farklı süreçlerin etkisinde gelişmiştir. Boğaz, Yarlıca Dağı doğusunda, Yarlıca Antiklinali'nin doğuya doğru alçaldığı yamaçlarda oluşmuştur. Boğaz, antiklinalin en fazla alçaldığı alan dışında açılmıştır. Boğazla kesilen kireçtaşı tabakaları, boğazın doğusunda monoklinal bir yapı kazanmıştır. Öyle ki boğazın kuzeyinde Akpınar Mahallesi yakınlarında bu tabakalar kuestaları oluşturmuştur (Fotoğraf 11). Özellikle boğazın kuzeyinde, boğazın her iki yamacında yer alan kireçtaşı tabakalarının eğimleri arasında bir uyumsuzluk bulunmaktadır. Bu uyumsuzluk Cendere Çayı'nın, Cendere Boğazı'n- 
da bir faya yerleştiğini göstermektedir. Nitekim, Kızıldağ doğusunda KB-GD doğrultulu fayın devamı bu boğaza karşılık gelmektedir.

Karadoğan ve Tonbul (2013), Yarlıca Dağı güney yamaçlarındaki fay aynalarında gençleşme izlerini dikkate alarak, Cendere Boğazı'nın tipik bir antesedans boğaz olduğunu belirtmişlerdir. Fakat, Cendere Boğazı güneyinde ve Cendere Köprüsü'nün doğusundaki tepede ve bu tepenin kuzeyindeki tepelerde taraça dolgularının varlığı epijenik oluşumu göstermektedir. Bu dolguların sadece doğu yamaçta yer alması ve boğazın tabaka eğimine ters yönde açılmış olması, bu oluşumu tartışmalı hale getirmektedir. Bütün bu veriler değerlendirildiğinde Cendere Çayı'nın Pleyistosen'in ilk dönemlerinde eğim yönünde konsekant aktığı bir dönemde Yarlıca Dağı doğu yamaçlarını kesen fay hattına yerleştiği daha sonra bölgesel yükselmelere ayak uydurarak günümüzdeki yapısını kazandığı anlaşılmaktadır. Kısaca başlangıçta epijenik hareketler, daha sonra sübsekant ve en sonunda da antesedans hareketlerin etkisinde gelişmiş bir boğazdır (Karataş, 2012; Sunkar ve Karataş, 2012a).

Cendere Boğazı oluşum ve doğal güzelliği dışında tarihi önemi olan bir alandır. Komagene Kırallığı döneminde yapılmış olan tarihi Cendere Köprüsü, her yıl binlerce turist tarafından ziyaret edilmektedir (Fotoğraf 11).

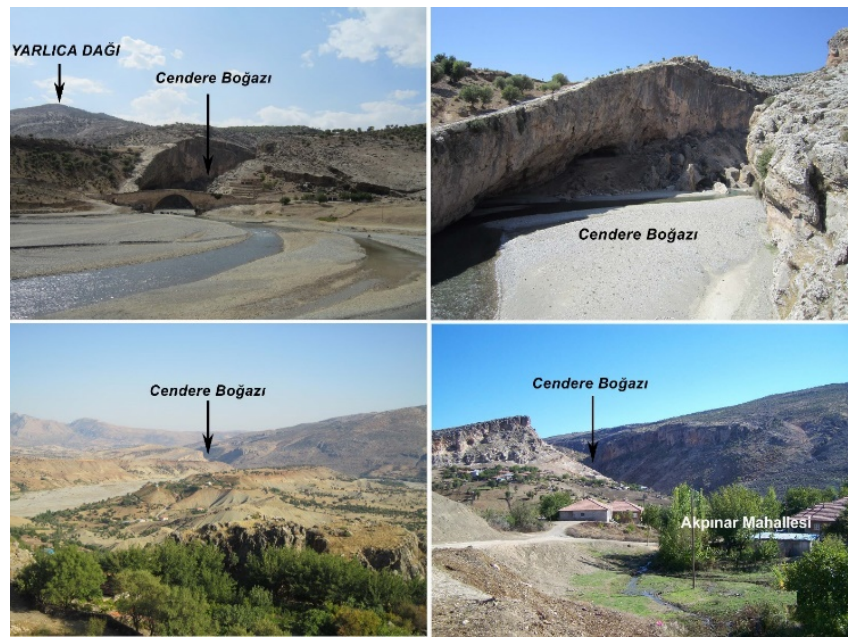

Fotoğraf 11. Yarlıca Dağı doğusunda Alikan ve Gebeli havzalarını birleştiren Cendere Boğazı.

Photo 11. Cendere Strait which combines Alikan and Gebeli basins in the east of Mount Yarlica.

\section{Gölgeli Boğazı}

Kuzeyde Sincik ile Alikan havzalarını birleştiren boğaz, tarafımızdan Gölgeli Boğazı olarak adlandırılmıştır. Bu boğaz, Alikan Havzası'nı kuzeyden sınırlandıran ve Eosen kireçtaşlarından oluşan antiklinalin Gölgeli Çayı tarafından yarılması ile oluşmuştur (Fotoğraf 12).

Antiklinal'in kuzey ve güney yamaçlarının faylarla kesilerek yükselmiş olması, boğazın antesedans oluşumlu olduğunu göstermektedir. Diğer boğazların oluşumundaki karmaşık yapı bu boğazda görülmemektedir. Alikan Havza- sı'nın batı bölümünden havzaya giren Recep Çayı da bu alandaki Eosen kireçtaşlarını yararak antesedans oluşumlu bir boğaz oluşturmuştur.

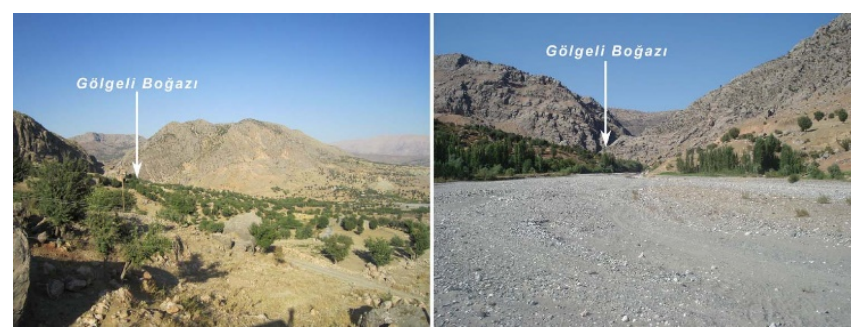

Fotoğraf 12. Alikan Havzası kuzeyinde Gölgeli Çayı'nın açmış olduğu Gölgeli Boğazı.

Photo 12. Gölgeli Strait formed by Gölgeli Stream in the north of Alikan Basin.

\section{Eski Kale Boğazı}

Kahta Çayı Aşağı Havzası'nda ana kol dışında, yan kollar üzerinde küçük çaplı boğazlar görülmektedir. Gebeli Havzası'nın kuzeydoğusunda Kocahisar yakınlarındaki Eski Kale Boğazı bunların en ilgincidir (Fotoğraf 13). Doğuya bakan yamaçlarında Eski Kahta Kalesi (Arsemia) yer almaktadır.

KD-GB doğrultuda uzanan boğazın derinliği $80 \mathrm{~m}$, uzunluğu ise yaklaşık $400 \mathrm{~m}$ kadardır. İnceleme alanındaki tektonik yapılar dikkate alındığında antesedans oluşumlu olduğu görülmektedir.

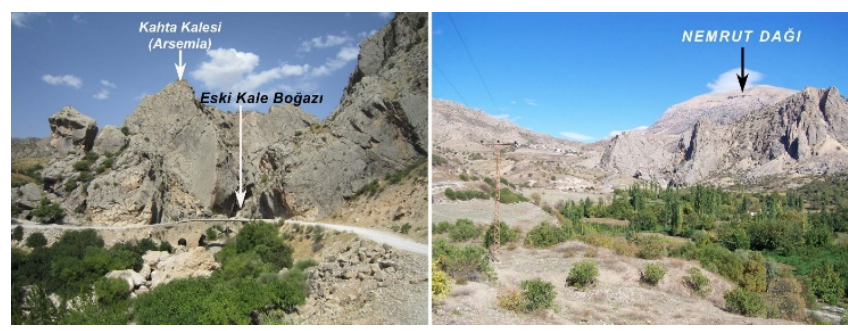

Fotoğraf 13. Kocahisar yakınlarında yer alan ve Kahta Çayı tarafından oluşturulan Eski Kale Boğazı.

Photo 13. Eski Kale (Old Castle) Strait formed by Kahta Stream and located in the Kocahisar neighbourhood.

\section{Birikinti koni ve yelpazeleri}

Kahta Çayı Aşağı Havzası'nın plato karakteri belirgin ve genelde bir boşalma havzası olduğu için tipik birikinti koni ve yelpazeleri gelişememiştir. Fakat bazı yan kolların ana akarsuya kavuştuğu alanlarda birikinti koni ve yelpazeleri oluşmuştur. Yarlıca Dağı güneyinde, Doluca-Teğmenli arasında ve Küsuh Boğazı güneyinde, Kahta Çayı ve baraj gölüne bağlanan akarsuların ağızlarında, yeni sayılabilecek birikinti koni ve yelpazeleri görülmektedir (Fotoğraf 14)

Kahta çevresinde Şelmo Formasyonu'nun üst üyesini oluşturan kalın konglomera tabakalarının çok hızlı ayrışması, bu alandaki yan kolların fazla malzeme taşımasını sağlamıştır. Taşınan bu malzeme, Şelmo Formasyonu'na ait gevşek litolojilerden sağlanmaktadır. Yan kollar mevsimlik ve çoğu sel karakterli olduğundan, oluşan birikinti koni ve yelpazeleri adeta her yıl yenilenmektedir. 

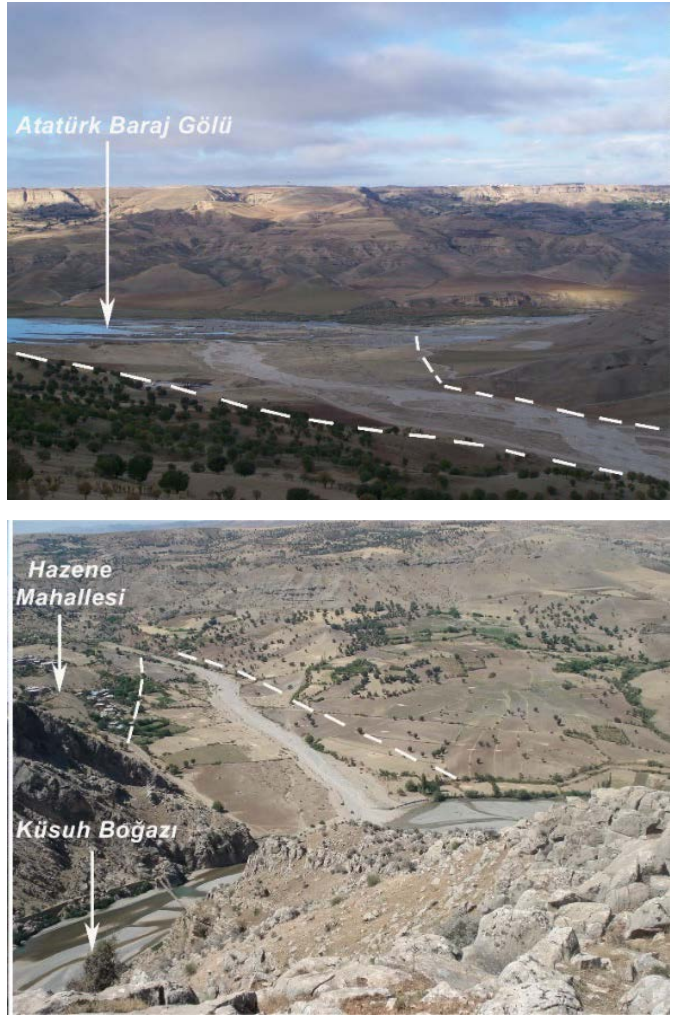

Fotoğraf 14. Kızıldağ güneyinde Gölgeli yerleşmesi batısında baraj gölü kıyısında oluşan yelpaze ile Küsuh Boğazı kuzeyinde Hazene Mahallesi yakınında oluşan birikinti konisi.

Photo 14. The alluvial fan formed in the coast of dam lake in the west of Gölgeli which is in the south of Kızıldağ and the alluvial cone formed in the neighbourhood of Hazene in the north of Küsuh Strait.

Eğim değeri yüksek dik yamaçların önlerinde fiziksel parçalanma ile oluşan koni şeklindeki birikim depoları etek döküntülerini (kayşat) oluşturmaktadır. Bu oluşumlar, Nemrut Dağı kuzey yamaçlarında tipik olarak görülmekte$\operatorname{dir}$ (Fotoğraf 15).

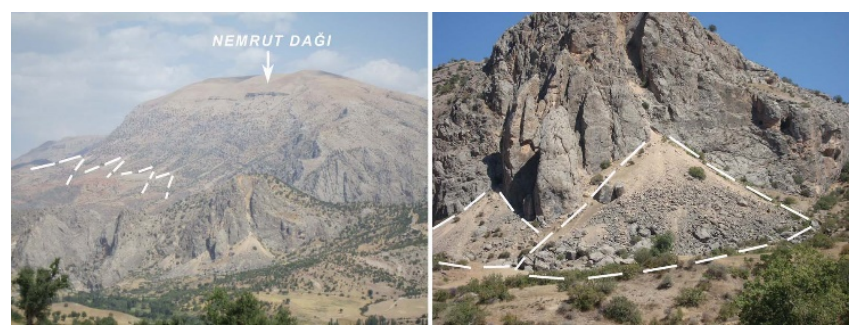

Fotoğraf 15. Nemrut Dağı kuzey yamaçları (a) ve Eski Kahta Boğazı güneyinde (b) görülen kayşat konileri.

Photo 15. Mount Nemrut north slopes (a) and the scree cones seen in the south of Old Kahta Strait.

\section{Kahta Çayı taraçaları}

Adıyaman Havzası'na yönelik yapılan jeomorfoloji çalışmalarında, Kahta Çayı'na bağlı oluşan taraçalar, Göksu Çayı taraçaları referans alınarak (T1 100-110 m; T2 70-80 m; T3 30-40 m ve T4 10-15 m) başlıca dört grupta toplanmıştır (Karadoğan, 2005; Karadoğan ve Tonbul, 2013). Fakat tarafımızdan doğrudan Kahta ve Göksu çayı tara- çalarına yönelik yapılan incelemelerde bu gruplandırmadan kısmen farklı sonuçlara ulaşılmıştır. Karadoğan'ın (2005) doktora tez çalışması doğrudan Adıyaman Havzası'na yönelik olduğu için taraçalar genel olarak değerlendirilmiştir. Bu nedenle ulaşılan sonuçlar arasında bir uyuşmazlık söz konusu değildir.

Kahta Çayı taraça depoları, Cendere Köprüsü'nden sonra geniş alan kaplamakta olup, havzada yüzeyleyen birimlere ait çakıllardan oluşmaktadır. Cendere Boğazı'ndan sonra, geniş alanlı olarak görülen taraça dolgularının kalınlığı, bazı alanlarda 60 m'yi bulmaktadır. Cendere ve Küsuh boğazları arasında belirgin olan kalın taraça depolarında düzenli bir istiflenme söz konusu değildir. Bu alanda dolguları oluşturan iri çakıllarda gözlenen yaslanma (kiremitlenme), Kahta Çayı'nın geçmişteki akış yönü ile günümüzdeki akış yönünün aynı olduğunu göstermektedir (Sunkar ve Karataş, 2011).

Kahta Çayı, yukarı havzada önemli ölçüde tektonik hatlara yerleşmiştir. Bu nedenle yukarı havzada tipik taraça oluşumu gözlenmemektedir. Fakat inceleme alanını oluşturan aşağı havzada, çok tipik taraçalar oluşmuştur. Kuvaterner'de görülen şiddetli tektonik hareketler ve iklim değişmeleri sonucunda, Kahta Çayı Aşağı Havzası'nda tipik taraça sistemleri gelişmiştir. Pleyistosen'deki kurak dönemlerde yukarı havzada şiddetli erozyonla taşınan malzeme, aşağı havzada geniş vadi tabanlarında biriktirilmiştir. Buzul dönemlerine karşılık gelen pluviyal dönemlerde ise akarsuların enerjileri artarak, bu dolgular yarılmış ve taraçalar oluşmuştur. Ayrıntılı arazi çalışmaları sonucunda, Kahta Çayı vadi tabanına göre farklı yükseltilerde 6 taraça sistemi (T1 90-120 m; T2 50-70 m; T3 30-40 m; T4 10-20 m; T5 3-5 $m$ ve T6 1-2 m) belirlenmiştir. Bunlardan 1-2 m taraçaları 3$5 \mathrm{~m}$ taraçalarına dahil edilerek sayı 5'e düşürülmüştür (Sunkar ve Karataş, 2012b).

Kahta Çayı taraçalarının tamamı genç tektonik hareketlerden etkilenmiştir. Bazı alanlarda Cendere Boğazı çevresinde olduğu gibi yükselmiş, kesilmiş ve deforme edilmiştir. Cendere Köprüsü doğusundaki ikinci tepede en yüksek T1 taraçası, vadi tabanına göre 160 m yüksekte yer almaktadır. Bir bölümü de Kahta doğusunda olduğu gibi kütle hareketleri ile bozulmuştur. Bu özellikler bölgede tektonik hareketlerin çok aktif olduğu, bölgenin bir sıkışma ve yükselme alanı olduğunu göstermektedir. Taraçalar hem tarım alanı olarak kullanılmakta hem de kum ocakları tarafından işletilmektedir.

\section{Karstik şekiller}

Kahta Çayı Aşağı Havzası'nda, Eosen-Oligosen döneminde oluşan kireçtaşları üzerinde, karstik şekillerden lapya ve dolinler oluşmuştur. Dolinler, Kızıldağ ve Yarlıca Dağı üzerindeki düzlüklerde gelişme ortamı bulmuştur. Ayrıca Kızıldağ üzerinde delikli lapyalar, Yarlıca Dağı üzerinde çıplak yüzeyde oluklu lapyalar gelişmiştir (Fotoğraf 16).

Karstlaşma etkisiyle Cendere Boğazı'nda ve Küsuh Boğazı çıkışında kireçtaşları üzerinde mağaralar oluşmuştur. Küsuh Boğazı çıkışında bir bölümü insan eli ile yapılmış olan 
mağaralar, tarihi dönemlerde insanlar tarafından kullanılmıştır (Karadoğan ve Tonbul, 2005; Fotoğraf 17).

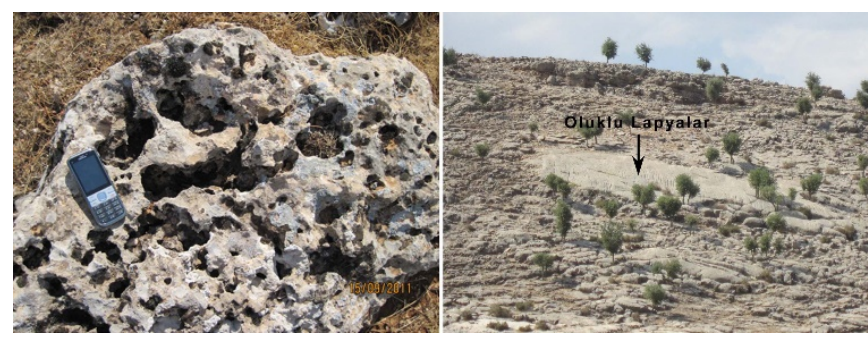

Fotoğraf 16. Kızıldağ üzerinde gelişen delikli lapyalar (a) ve Yarlıca Dağı güneyinde Yünlü Mahallesi kuzeyinde gelişen oluklu lapyalar (b).

Photo 16. Lapies with holes (a) evolving on Kızıldağ and lapies with hollows evolving in the north of Yünlü district in the south of Mount Yarlıca.

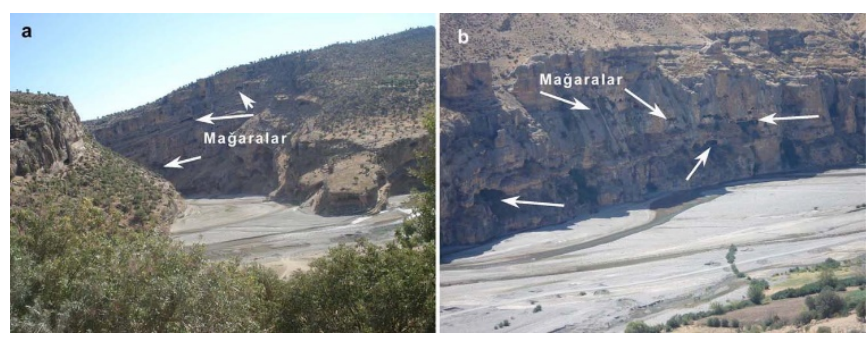

Fotoğraf 17. Cendere (a) ve Küsuh (b) boğazlarında oluşan karstik mağaralar tarihi dönemlerde yerleşme amacıyla kullanılmıştır.

Photo 17. The carstic caves formed in Cendere (a) and Küsuh (b) straits had been used as a settlement in the ancient time.

\section{Kütle hareketleri}

Kahta Çayı Aşağı Havzası'nın jeolojik ve jeomorfolojik özellikleri nedeniyle heyelan alanları dikkat çekici boyutta geniş alan kaplamaktadır (Şekil 4). Üst Miyosen birimlerinin geniş alanlarda yüzeylemesi ve bu birim içerisinde killi marnlı yapının önemli yer tutması geniş alanlı heyelanlara neden olmuştur. Şelmo Formasyonu'nun Kahta Çayı tarafından yarılması ve faylanma etkisiyle derin bir şekilde parçalanmış olması sürecin devamını sağlamaktadır.

Kahta Çayı Aşağı Havzası'nda heyelanlar en yoğun olarak Gebeli Havzası çevresinde görülmektedir (Şekil 4). Bu havzada, taraça dolguları dışında kalan alanların tamamına yakını heyelanlı bölgeleri oluşturmaktadır. Büyük bölümü yavaş gelişmekte olan bu heyelanlar yerleşme, ulaşım ve tarım alanlarını etkilemektedir (Foto 18).

Kahta doğusunda, Kahta Vadisi'nin batı yamaçları faylarla kesilerek basamaklı bir yapı kazanmış geniş alanlı heyelan bölgesidir. Heyelanlar, bu yamaçtaki taraçaları deforme etmiştir. Çok geniş alanlı olan heyelanlar, Damlacık çevresinde olduğu gibi bazı dönemlerde kara yolunu deforme etmekte olup, yolun çok sayıda kavislilerden oluşmasına neden olmuştur (Şekil 4). Heyelan bölgelerinde, heyelanla birlikte kaya düşmeleri de yaşanmaktadır. Kızıldağ, Nemrut
Dağı ve Yarlıca Dağı kuzey yamaçları kaya düşmelerinin sık görüldüğü alanlardır (Fotoğraf 18).

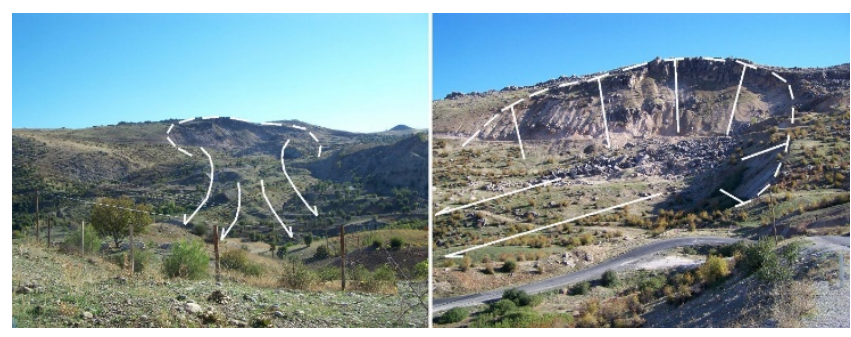

Fotoğraf 18. Küsuh Boğazı kuzeyinde Hazene Mahallesi batısında yerleşme ve tarım alanları ile ulaşımı etkileyen geniş alanlı heyelan.

Photo 18. A wide landslide that affected settlement and agricultural fields in the west of Hazene district in the north of Küsuh Strait.

\section{Yapısal şekiller}

Kahta Çayı Aşağı Havzası'nda yatay, kıvrımlı, kırıklı ve monoklinal yapılara özgü yer şekilleri bulunmaktadır. Kahta ile kuzeydeki dağıı alan arasında, Üst Miyosen dönemine ait kalın konglomera tabakalarının yarılmasıyla çok tipik kornişler oluşmuştur (Foto 4). İnceleme alanının doğusunda inceleme alanı sınırı dışında kalan alanlarda ise mesalar görülmektedir (Fotoğraf 19).

Aşağı havzanın kuzey bölümü, kıvrımlı yapı özelliği göstermekte olup kuzeyden güneye doğru KD-GB doğrultusunda uzanan antiklinal ve senklinallerden oluşmaktadır. Antiklinaller dağlık alanları oluşturmakta olup, alçaldığı alanlarda Kahta Çayı tarafından yarılarak klüzler oluşmuştur. Bir bölümü inceleme alanı dışında devam eden bu antiklinaller üzerinde komb, rüz ve klüzlere sık rastlanmaktadır.

Kahta kuzeyinde görülen monoklinal şekiller, tektonik hareketlerin neden olduğu deformasyonlar sonunda oluşmuştur. İnceleme alanında monoklinal yapılar iki şekilde oluşmuştur. Bunlardan ilki Kahta kuzeyinde bindirme etkisinde oluşan şekiller, ikincisi de Kahta kuzeyinde, Üst Miyosen birimlerinin güneye çarpılmalarıyla oluşan monoklinal şekillerdir. Kuzeyde çok tipik kuesta ve hogbekler oluşurken, Kahta kuzeyinde çok basık kuestalar oluşmuştur. Yarlıca Dağı doğusunda Kocahisar çevresinde ise Karadoğan'ın (2005) da belirttiği gibi kretler bulunmaktadır.

Alikan Havzası'nı kuzeyden sınırlandıran bindirme alanlarında nap, klip ve tektonik pencereler bulunmaktadır.

Kırıklı yapılardan en tipik olanları fay dikliklerinin bulunduğu alanlardaki fay aynalarıdır. Yarlıca Dağı güney yamaçlarında, tipik fay aynaları görülmektedir. İnceleme alanında yer şekillerinin çok zengin olmasında kırıklı yapının rolü büyüktür. Bu şekiller önceki konularda ayrı ayrı değerlendirildiği için burada tekrar edilmemiştir. 


\section{Jeomorfolojik Gelişim}

Kahta Çayı Havzası, Güneydoğu Toroslar ile Kenar kıvrımları kuşağında yer almaktadır. Bu konumu nedeniyle, Alp orojenezinin son safhasındaki hareketlerden fazla etkilenmiştir. Kahta Çayı Aşağı Havzası'nın jeomorfolojik gelişimi, içerisinde yer aldığı bölgenin jeomorfolojik gelişimi ile uyumludur. Bu süreçte, Orta Miyosen'de AnadoluArap levhalarının çarpışmasına kadar olan dönemde gelişen yapılar Paleotektonik, Orta Miyosen'den günümüze kadar olan dönemde oluşan yapılar ise Neotektonik dönemi temsil etmektedir (Erol, 1983). Incelenen sahanın jeomorfolojik gelişiminde hem Paleotektonik, hem de Neotektonik hareketlerin etkisi görülmektedir. Kahta Çayı Havzası'nda mevcut yer şekillerinin oluşumunda Neotektonik hareketlerin etkisi daha belirgindir. Bu nedenle Paleotektonik dönem değerlendirmelerinde bölgesel ölçekli yorumlar kullanılmıştır.

\section{Paleotektonik dönem}

Toros Dağları ve Torid Kuşağı, Neotetis'in güney kanadını kapsamakta olup, otokton birimlerle, kuzeyden gelmiş örtü birimlerinden oluşur (Şengör, 1980). Jeosenklinal güneydeki Arabistan bloğu üzerine Kampaniyen yaşlı itilmelerle Üst Kretase'den itibaren kapanmaya başlamış ve bu kapanma, Türkiye'nin bugünkü genç tektonik zeminini yaratan, Orta Miyosen kıta-kıta çarpışması ile sona ermiştir (Erol,1983).

Inceleme alanının içerisinde yer aldığı alan, Üst KretaseGeç Miyosen aralığında deniz etkisinde kalmıştır (Öğrenmiş, 2006). Orta Miyosen'de Anadolu-Arap levhalarının çarpışması ile tektonik açıdan yeni bir dönem başlamıştır.

\section{Neotektonik dönem}

Paleotektonik dönem sonunda, Orta Miyosen'de kıta-kıta çarpışması olayı mikro tablaların faylanması ve biçim değiştirmesi şeklinde yeni bir değişim (neotektonik) dönemi meydana getirmiştir (Şengör 1980). Neotektonik olarak ifade edilen bu yeni dönem boyunca bölgedeki tektonizma kratonik bir nitelik kazanmış, daha çok düşey yöndeki hareketler ön plana çıkmıştır. Sıkışma rejimi ile birlikte bölgede kıvrılmalar, bindirmeler, doğrultu atımlı faylar, açılma çatlakları gelişmiş, bu yapılar kıta kabuğunun yoğun deformasyonuna neden olmuştur. Bu yükselme nedeniyle deniz bölgeden çekilmeye başlamıştır (Şaroğlu ve Yılmaz,1986).

Adıyaman Havzası'nın Neotektonik gelişimi ile inceleme alanının neotektonik gelişimi aynı özelliklere sahiptir. Bu nedenle Karadoğan (2005) tarafından ileri sürülen model inceleme alanı için de geçerli olmaktadır. Buna göre;

Orta Miyosen'den önce orojenik yükselmeler ön planda iken, Orta Miyosen'den sonra blok tektonizması altında dikey yükselmeler ön plana çıkmıştır. Bu süreçte dağlık alanlar kırılmalarla birlikte toptan yükselmiştir. Dağlık alanlar bindirme kuşakları boyunca sürüklenmeye başlamış ve böylece dağlık alanlar arasında bindirme cepheleri boyunca küçük ölçekli havzalar oluşmuştur. İnceleme alanında yer alan senklinal havzaları bu dönemden sonra belirmeye başlamıştır. Adıyaman Havzası da bu dönemden sonra belirginleşmiştir.

Miyosen sonlarında kurak ve yarıkurak iklim şartları altında havza tabanına doğru eğimli pediment yüzeyleri oluşmuştur. Üst Miyosen-Alt Pliyosen'de bu dönemden önce oluşan alanlar yükselerek güneydeki havza arasında çok belirgin yükselti farkları oluşmuştur. Bu dönemde beliren yeni taban seviyesine göre, yüksek alanlar aşındırılarak havza tabanında kalın istiflerden oluşan Şelmo Formasyonu'nu oluşturmuştur.

Pliyosen'de şiddetli aşınım ve yarılma süreci yaşanmıştır. Bu dönemde dikey yönlü yükselmeler artmış ve havzalar ile çevresindeki yüksek alanlar arasında yükselti farkı iyice belirginleşmiştir. Havzaları kapan veya birleştiren akarsular, yataklarını derine kazarak dar ve derin boğazlar oluşturmaya başlamıştır. Alçalan taban seviyeleri nedeniyle yatağını derinleştiren bazı yerel akarsuların geriye aşındırması ile boğazları kazarak havzaları birbirine bağlamıştır. Böylece Üst Pliyosen sonlarına doğru oluşan yassı bir rölyef üzerinde tek bir akarsu, Fırat Nehri doğmuştur (Erol vd., 1987).

Pliyosen ile Kuvaterner arasında ve Kuvaterner boyunca Türkiye'de coğrafi şartlarda belirgin hızlı değişmeleri yansıtan geçişler görülmemektedir. Pliyosen ve Kuvaterner'de karasal ve günümüz iklimine benzeyen yarıkurak iklim şartları yaşanmıştır. Pliyosen'de sel-yüzeysel aşınmaçamur birikimi, Kuvaterner'de akarsu-vadi gelişimi ve alüvyon birikimi ana oluşumlardır. Bu oluşumlarda belirgin değişmeler yerine, yavaş veya salınımlarla silikleşen geçişlerin devamlılığı oluşturduğu söylenebilmektedir (Kayan, 1997).

Bölgeyi etkileyen tektonik hareketler Kuvaterner'de de devam etmiş, hatta en az Pliyosen'e kadar şiddetli olmuştur. Bu dönemdeki bindirme yapıları doğrultu atım kazanmış, havzalar ile çevresindeki yüksek alanlar arasındaki yükselti farkı iyice artmış olup, boğazlar daha da derinleşmiştir. Bugünkü kurak bölgeler, Pleyistosen'deki buzul çağlarının karşılığı olan pluviyal dönemlerde fazla yağış sonucunda akarsular daha fazla güçlenerek, önceki kurak dönemde birikmiş olan çakıllı dolguları yararak taraçalar oluşturmuştur (Erol, 1979). Pleyistosen'de yaşanan iklim değişmeleri ve tektonik hareketler sonrasında, Kahta Çayı yatağı içerisine dönemler halinde gömülerek günümüzdeki yapısını almıştır. Her dönemde bir taraça sistemi oluşarak vadi boyunca çok belirgin olmak üzere 5 taraça sistemi gelişmiştir.

\section{SONUÇLAR}

Kahta Çayı Havzası, Adıyaman Havzası kuzeyinde Güneydoğu Toroslar ve Kenar Kıvrımları Kuşağı üzerinde yer almaktadır. Kahta Çayı Aşağı Havzası, Türkiye'nin önemli tektonik yapılarından Güneydoğu Anadolu Bindirmesi, Doğu Anadolu Fayı ve Adıyaman Fayı tarafından deforme olmuş engebeli bir yapı göstermektedir. Kıvrımlı 
ve kırıklı yapı özelliği nedeniyle dağlık alanlar yükselmiş, bu yükselmeye ayak uyduran akarsular bu yapıları kesmiştir. Böylece geniş plato alanları (Yüksek ve alçak platolar) oluşmuştur. Kıvrımlanma hareketleri ile beliren dağlık alanlar, daha sonra oluşan faylarla kesilerek yükselmiş adeta horst yapısı kazanmışlardır. Fayların kestiği yamaçlarda belirgin fay diklikleri ve yoğun kütle hareketleri yaşanmaktadır. Bu dağlık alanlarda, litolojik yapı kalın kireçtaşlarından oluştuğu için dağlık sahalar üzerinde dolin ve lapyalar gelişmiştir.

Kahta Çayı Havzası'nın şekillenmesinde Pliyosen ve Kuvaterner döneminde belirginleşen genç tektonik hareketler etkili olmuştur. Fırat Nehri'nin önemli kollarından biri olan Kahta Çayı, bölgesel ölçekli yükselmelere ayak uydurarak yatağı içerisinde yer yer menderesli bir şekilde gömülmüştür. Bu süreçte Kahta Çayı, havza kuzeyinde antiklinalleri kestiği alanlarda antesedans, güneyde epijenik boğazlar oluşturmuştur. Oluşum açısından antiklinaller üzerinde gelişen bu boğazlar, aynı zamanda tipik birer klüze karşılık gelmektedir.

Kahta Çayı Aşağı Havzası'nda antiklinaller arasında senklinallere karşılık gelen ancak faylarla şekillendirilmiş olan dar alanlı Alikan ve Gebeli havzaları oluşmuştur. Üst Miyosen'de beliren bu havzalar, oluşumlarını takip eden dönemde Miyosen ve Pliyo Kuvaterner dolguları ile doldurulmuştur. Bu dolgular, Kuvaterner'de enerjisi artan Kahta Çayı tarafından yarılmıştır. Günümüzde ise bu havzalarda Kahta Çayı, tipik örgülü drenaj ağına sahiptir.

Kahta Çayı Havzası'nın bulunduğu alan, Anadolu ve Arap levhalarının çarpışmasını takip eden dönemde hızlı yükselerek şiddetli aşındırma faaliyetleri başlamıştır. Bu dönemde, kuzeyde aşınan malzeme hemen güneydeki havzada biriktirilerek kalın sedimanter dolgular oluşmuştur. Pleyistosen döneminde de sıkışma ve doğrultu atımlı tektonik rejim altında sahanın yükselmesi ve iklim değişmelerine bağlı olarak şiddetli erozyon yaşanmıştır. Şiddetli erozyonla taşınan sedimentler, Kahta Çayı Vadisi'nde biriktirilmiştir. Daha sonra enerjisi artan Kahta Çayı, bu dolguları yararak geniş alanlı taraçalar oluşmuştur. Kahta Çayı Aşağı Havzası'daki taraçaların oluşumunda, iklim değişmeleri ile birlikte tektonik hareketlerin ön planda olduğu görülmüştür. Kahta Çayı Yukarı Havzası sürekli ve hızlı bir yükselim alanı olduğu için taraçalar aşağı havzada tipik olarak görülmektedir. Vadi tabanına göre olan yükseltilerine göre, 6 taraça basamağı belirlenmiştir. Bunlar; T1 90120 m; T2 50-70 m, T3 30-40 m, T4 10-20 m, T5 3-5 m ve T6 1-2 m taraçalarıdır. Fakat bunlardan 1-2 m taraçaları her yerde belirgin olmadığı için bu taraçalar 3-5 m taraçalarına dahil edilmiştir.

Kahta Çayı Havzası'nda yaşanan şiddetli erozyon, geçmişten günümüze kadar devamlılığını sürdürmektedir. Kahta Çayı'nın Atatürk Baraj Gölü'ne döküldüğü alanda görülen alüvyal boğulma bu açıdan oldukça dikkat çekicidir.

\section{KATKI BELIRTME}

Bu çalışma TÜBiTAK 110 Y363 nolu "Kahta Çayı (Adıyaman) Taraçalarının Kuvaterner Jeomorfolojisi" başlıklı proje kapsamında hazırlanan, Yüksek Lisans Tez çalışmasından üretilmiş olup destekleri nedeniyle TÜBiTAK'a teşekkür ederiz.

\section{KAYNAKLAR}

Atalay, i. (1994). Türkiye Coğrafyası (Genişletilmiş 4. Baskı), Ege Üniversitesi Basımevi, İzmir.

Atalay, İ. ve Mortan, K. (2006). Türkiye Bölgesel Coğrafyası, Genişletilmiş 3. Baskı, İnkılap Kitapevi, İstanbul.

Atalay, İ., Günek, H. ve Karadoğan, S. (2002). “Nemrut Dağı'nın Doğal Ortam Özellikleri ve Turizm Potansiyeli". Türkiye Dağları I. Sempozyumu, 25-27 Haziran, Bolu.

Darkot, B. (1943). “Türkiye'nin Coğrafi Bölgeleri Arasında Yukarı Fırat Bölgesi". III. Üniversite Haftası, Elazığ 1943, İstanbul Üniversitesi Yayınları, No: 196, 225-268.

Demir, T., Yeşilnacar, I. ve Westaway, R., (2004), "River terrace sequences in Turkey: sources of evidence for lateral variations in regional uplift" Proceedings of the Geological Association, 115(4), 289-311.

Elmastaş, N. (2008). "Kahta Çayı Havzası'nda Arazi Kullanımı", Coğrafi Bilimler Dergisi, 6(2), 159-190, Ankara.

Erinç, S. (1953). Doğu Anadolu Coğrafyası, İstanbul Üniversitesi Coğrafya Enstitüsü Yayınları, 28, İstanbul.

Erinç, S. ve Bilgin, T. (1956). "Türkiye'de Drenaj Tipleri", İstanbul Üniversitesi Coğrafya Enstitüsü Dergisi, 4(7), 124-156, İstanbul.

Erinç, S., (1996), Jeomorfoloji I, (Genişletilmiş 4. Baskı), Öz Eğitim Basım Yayın Dağıtım Ltd. Şti, Konya.

Erol, O. (1979). “Türkiye'de Neojen ve Kuvaterner Aşınım Dönemleri, Bu Dönemlerin Aşınım Yüzeyleri ile Yaşıt (korelant) Tortullarına Göre Belirlenmesi", Jeomorfoloji Dergisi, 8, 1-40, Ankara.

Erol, O. (1983). "Türkiye'nin Genç Tektonik ve Jeomorfolojik Gelişimi", Jeomorfoloji Dergisi, 11, 1122, Ankara.

Erol, O., Akkan, E., Elibüyük, M. ve Doğu, A. F. (1987). Aşağı Fırat Bölgesi'nde Bugünkü ve Kuvaterner'deki Doğal Çevre Koşulları - The Present and Quaternary Natural Enviromental Conditions in the Lower Euphrates Region, Aşağı Fırat Projesi, 1978-1979 Çalışmaları, ODTÜ, Aşağı Fırat Projesi Çalışmaları, Seri: I, No:3, Ankara.

Günay, Y. (1998). Güneydoğu Anadolu'nun Jeolojisi, TPAO Arşivi, Rapor No: 3939.

İnceöz, M., Aksoy, E., Zengin, E. (2003). “Adıyaman Fay Zonu'nun Palu-Fırat Nehri Arasındaki Bölümünün Morfotektonik Özellikleri". ATAG-7 Aktif Tektonik Araştırma Grubu 7. Toplantısı, Yüzüncüyıl Üniversitesi Jeoloji Mühendisliği Bölümü, 01-03 Ekim 2003 Van.

İnceöz, M. ve Zengin, E., (2014), “Adıyaman Fay Zonunun Morfotektonik ve Yapısal Özellikleri", Fırat Üniversitesi Mühendislik Bilimleri Dergisi, 26 (2), 131-148. 
Karadoğan, S. (2005). Adıyaman Havzasının Genel ve Uygulamalı Jeomorfolojisi, Fırat Üniversitesi Sosyal Bilimler Enstitüsü. Doktora Tezi (Yayınlanmamış), Elazığ.

Karadoğan, S. ve Tonbul, S. (2005). “Adıyaman Havzasında Kuvaterner'deki Doğal Ortam Koşullarının Yerleşmelerin Dağılışı ve Diğer İnsan Faaliyetleri Üzerindeki Etkileri", Türkiye Kuvaterner Sempozyumu $V$, İstanbul Teknik Üniversitesi Avrasya Yerbilimleri Enstitüsü, 191-204, 2-5 Haziran 2005, İstanbul.

Karadoğan, S. ve Tonbul, S. (2013). “Adıyaman Havzası'nın Jeomorfolojik Özellikleri", Akademik Sosyal Araştırmalar Dergisi, 1, 182-217.

Karataş, Z. (2012). Kahta Çayı (Adıyaman) Taraçalarının Kuvaterner Jeomorfolojisi. Fırat Üniversitesi Sosyal Bilimler Enstitüsü Yüksek Lisans Tezi (Yayımlanmamış), Elazığ.

Kaya, T., Şen, Ş., Mayda, S., Saraç, G. ve Metaıs, G. (2012). "Adıyaman Dolaylarındaki (Güneydoğu Türkiye) Geç Miyosen Memeli Fosilleri" 65.Türkiye Jeoloji Kurultayı, 552-553, 2-6 Nisan 2012, Ankara.

Kayan, i. (1997). "Yeni Yaklaşımlarla Türkiye'nin PliyoKuvaterner Paleocoğrafyası", Türkiye Coğrafyası Araştırma ve Uygulama Merkezi Dergisi, 6, 189-199, Ankara.

Meriç, E. (1965). “Kahta-Nemrut Dağı arasındaki Bölgenin Jeolojik ve Paleontolojik Etüdü", İstanbul Üniversitesi, Fen Fakültesi Mecmuası, B, 30, (1-2), 55-107.

Öğrenmiş, I. Y. (2006). Adıyaman ve Kahta Dolaylarının Jeolojisi ve Petrol Potansiyeli. Fırat Üniversitesi Fen Bilimleri Enstitüsü, Yüksek Lisans Tezi (Yayınlanmamış), Elazığ.

Özdemir, F. ve Ünlügenç, U. Ç., (2013). “Gökiçi (Diyarbakır) Yapısının Stratigrafisi ve Hidrokarbon Potansiyeli Açısından İncelenmesi", Çukurova Üniversitesi Mühendislik Mimarlık Fakültesi Dergisi, 28(1), 127-141

Özdemir, M. A. ve Tonbul, S. (1996). “Kömürhan Boğazı (Malatya-Elazığ)", Fırat Üniversitesi Sosyal Bilimler Dergisi, 8(1), 239-262, Elazığ.

Perinçek, D., Günay, K. ve Kozlu, H. (1987). “Doğu ve Güneydoğu Anadolu bölgesindeki yanal atımlı faylar ile ilgili yeni gözlemler". Türkiye 7. Petrol Kongresi Bildirileri, 89- 103, Ankara.

Sungurlu, O., (1974). VI. Bölge Kuzey Sahalarının Jeolojisi, TPAO Arama Grubu, Rapor No: 871, 32s, Ankara

Sungurlu, O., Günay, Y., Semşir, D. ve Sarıdaş, B. (1991). Güney Anadolu Şaryaj Projesi, TPAO Adıyaman Bölge Müdürlüğü.

Sunkar, M. ve Karataş, Z. (2011). "Kahta Çayı (Adıyaman) Taraçalarının Sedimantolojik Özellikleri", Uluslararası Katılımlı Coğrafya Kongresi, 07-10 Eylül 2011, 498-506, İstanbul.

Sunkar, M. ve Karataş, Z. (2012a). Kahta Çayı (Adıyaman) Taraçalarının Kuvaterner Jeomorfolojisi. TÜBITAK, Proje No: 110Y363, 93 Sayfa.

Sunkar, M. ve Karataş, Z. (2012b). “Kahta Çayı (Adıyaman) Taraçalarının Morfometrik Özellikleri", UJES 2012, III. Ulusal Jeomorfoloji Sempozyumu (4-6 Ekim 2012), 106114 , Hatay.
Şaroğlu, F. ve Yılmaz, Y. (1986). “Doğu Anadolu'da Notektonik Dönemdeki Jeolojik Evrim ve Havza Modelleri", Maden Tetkik ve Arama Enstitüsü Dergisi, 107, 73-94, Ankara.

Şengör, A. M. C. (1980). Türkiye'nin Neotektoniğinin Esasları. Türkiye Jeoloji Konferanslar Serisi Yayınları No: 2.

Tanoğlu, A. (1944). "Malatya Dolaylarında Coğrafi Geziler II", Türk Coğrafya Dergisi, 5-6, 61-84, İstanbul

Yılmaz, E. ve Duran, O. (1997). Güneydoğu Anadolu Bölgesi Otokton ve Allokton Birimler Stratiğrafi Adlama Sözlügü, (LEXICON), Türkiye petrolleri Anonim Ortaklığı, Araştırma Gurubu Başkanlığı Eğitim Yayınları No: 1. 